\title{
O ALUMÍNIO TROCÁVEL DE UM SOLO PODZÓLICO VERMELHO-AMARELO DO ACRE E SUA ABSORÇÃO PELAS PLANTAS
}

\author{
JOSÉ RAIMUNDO NATIVIDADE FERREIRA GAMA \\ Engenheiro Agrônomo \\ Mestre
}

Orientador: Prof. Dr. JORGE DE CASTRO KIEHL

Tese apresentada à Escola Superior de Agricultura "Luiz de Queiroz" da Universidade de São Paulo, para obtenção do título de Doutor em Agronomia, Área de Concentração: Solos e Nutrição de Plantas.

P I R A C I C A B A

Estado de São Paulo - Brasil

Maio - 1995 


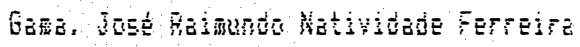

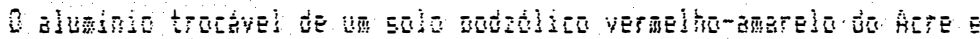

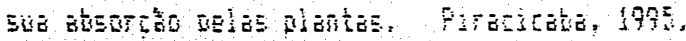

89. Tus.

TESE - ESAR

rHiveratis.

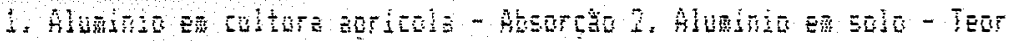

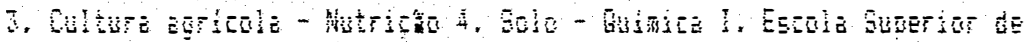

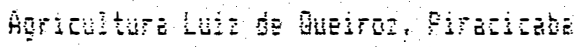




\title{
O ALUMÍNIO TROCÁVEL DE UM SOLO PODZÓLICO VERMELHO-AMARELO DO ACRE E SUA ABSORÇÃO PELAS PLANTAS
}

\author{
JOSÉ RAIMUNDO NATIVIDADE FERREIRA GAMA
}

Aprovada em: 11/08/95

Comissão julgadora:

Prof. Dr. JORGE DE CASTRO KIEHL

Prof. Dr. QUIRINO AUGUSTO DE CAMARGO CARMELO

Prof. Dr. TAKASHI MURAOKA

Dra. MARIA REGINA FREIRE MOLLER

Dr. ISMAEL DE JESUS MATTOS VIEGAS
ESALQ/USP

ESALQ/USP

ESALQ/USP

EMBRAPA/CPATU

EMBRAPA/CPATU

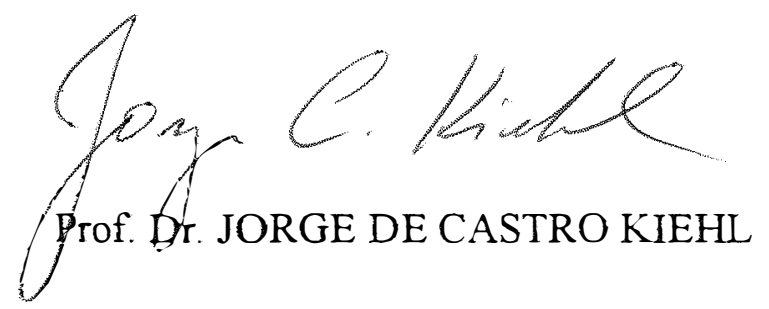


Pela vontade de sobreviver junto com a Ciência do Solo e pela coragem de ir até ao final deste curso,

\section{DEDICO e OFEREÇO}

este trabalho a mim mesmo,

GAMA. 


\section{AGRADECIMENTOS}

A todos que contribuíram, direta ou indiretamente na realização deste trabalho, expresso meus sinceros agradecimentos, em especial:

À Empresa Brasileira de Pesquisa Agropecuária (EMBRAPA) e à Escola Superior de Agricultura “Luiz de Queiróz” (ESALQ), pela oportunidade de realizar este curso, particularmente a todos os funcionários do CNPS/EMBRAPA.

Ao Prof. Dr. Jorge de Castro Kiehl, pela compreensão e amizade;

Ao Prof. Dr. Klaus Reichard, pela humildade e colaboração dispensada.

Ao Prof. Dr. Geraldo Victorino de França, coordenador do curso de Solos e Nutrição de Plantas, pela forma sempre amistosa, sincera e acima de tudo profissional com que sempre me atendeu;

A um grupo de amigos sinceros, honestos e leais com os quais muito aprendi no decorrer do curso, o que muito importante para a continuação da vida; são eles: Raimundo Assis Junior e Família, Rivaldo Vital dos Santos e Família, Reynaldo Rocha Beltran e Família, Eduardo Jorge Maklouf Carvalho e Familia e Marcos Cabral de Vasconcellos Barretto.

Às Bibliotecárias Kátia M. de Andrade Ferraz e Maria da Penha, pelo apoio;

Aos meus filhos Frederico e Felipe, à Ió, minha esposa e ao meu irmão João Carlos Ferreira, meus agradecimentos por tudo que representam para mirn.

Aos amigos do CNPS / EMBRAPA, José Silva de Souza e Claúdio Edson Chaffin pelo apoio dispensado. 


\section{SUMÁRIO}

Página

RESUMO

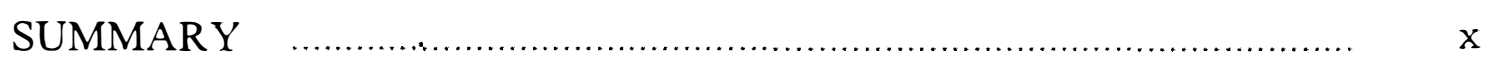

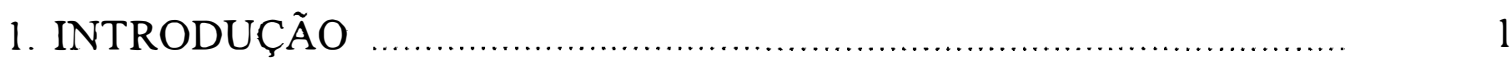

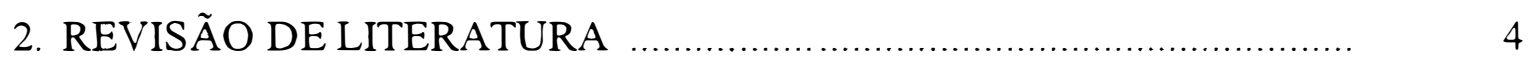

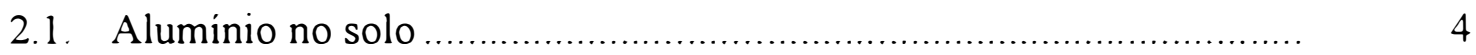

2.2. Toxicidade de alumínio nos vegetais ……...................................

2.3. Mecanismo de tolerância .......................................................... 13

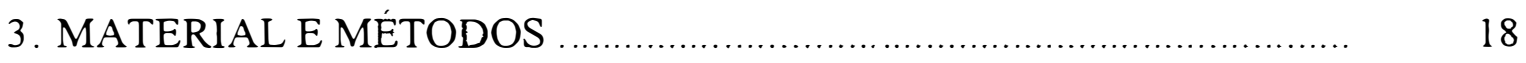

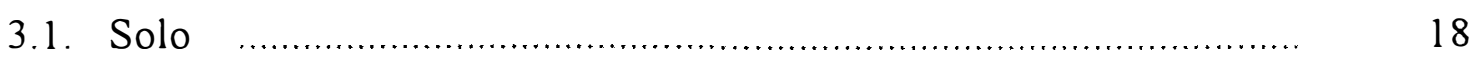

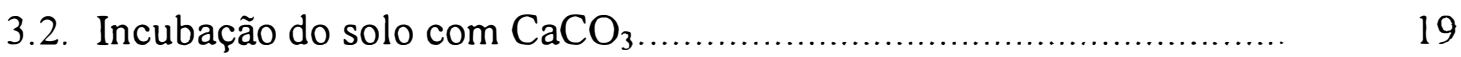

3.3. Experimento em casa-de-vegetação................................................. 21

3.4. Obtenção e análise do extrato de saturação ....................................... 22

4. RESULTADOS E DISCUSSÃO …................................................... 24

4.1. Alteração do $\mathrm{pH}$ e do teor de Alumínio trocável em amostras de solo incubadas com $\mathrm{CaCO}_{3}$, avaliadas por diferentes métodos

4.2. Comportamento das espécies e/ou cultivares plantadas em amostras de solo com elevado teor de alumínio

4.2.1. Teores de alumínio, nitrogênio, fósforo e potássio nas raizes das plantas

4.2.2. Teores de alumínio, nitrogênio, fósforo e potássio na parte aérea das plantas

4.2.3. Produção de material seco e quantidades de alumínio, nitrogênio, fósforo e potássio acumuladas nas plantas 
4.3. Avaliação do teor de alumínio na solução do solo.

5. CONCLUSÕES

REFERÊNCIAS BIBLIOGRÁFICAS

APÊNDICE 


\title{
O ALUMÍNIO TROCÁVEL DE UM SOLO PODZÓliCO VERMELO-AMARELO DO ACRE E SUA ABSORÇÃO PELAS PLANTAS
}

\author{
Autor:JOSÉ RAIMUNDO NATIVIDADE FERREIRA GAMA \\ Orientador: PROF. DR. JORGE DE CASTRO KIEHL
}

\section{RESUMO}

O solo Podzólico Vermelho-Amarelo, um dos mais representativos do Estado do Acre, apresenta características que o diferem dos demais podzólicos , como presença de vidros vulcânicos, material amorfo alofânico superior a 17\% e teores simultaneamente altos de cálcio, magnésio e alumínio trocáveis. Embora o teor de alumínio trocável ultrapasse $13 \mathrm{cmol}_{\mathrm{c} . \mathrm{dm}} \mathrm{dm}^{-3}$ em certas áreas, as plantas cultivadas nesse solo não tem apresentado sintomas de toxicidade desse elemento ou redução da produtividade. Neste trabalho, procurou-se investigar a causa da ausência desses sintomas de toxicidade.

Em um experimento, amostras dos horizontes A e B foram incubadas por 7 e 14 dias, com doses de carbonato de cálcio, procedendo-se às determinações do $\mathrm{pH}$ em água e em $\mathrm{CaCl}_{2}$ e do teor de aluminio trocável, extraído com solução de $\mathrm{KCl} 1 \mathrm{~N}$ e determinado por titulação com $\mathrm{NaOH} 0,025 \mathrm{~N}$ e por espectrofotometria de absorção atômica. Em outro experimento, quatro espécies ou cultivares (arroz, cultivares Fernandes e IAC 1131; feijão, cultivar Rosinha, e 
milho, cultivar C51 1-A) foram plantadas em vasos contendo $3 \mathrm{~kg}$ de terra tratados ou não com calcário visando elevar a saturação por bases a $80 \%$. Após 60 dias, nas raizes e na parte aérea foram efetuadas as determinaçòes de $\mathrm{Al}, \mathrm{N}, \mathrm{P}$ e $\mathrm{K}$.

Os teores de $\mathrm{Al}$ trocável obtidos por titulação com $\mathrm{NaOH}$ nas amostras incubadas com corretivo mostraram-se coerentes com os fornecidos por espectrofotometria de absorção atômica.

Mesmo com a acentuada redução do teor de Al trocável do solo pela aplicação do corretivo, o teor e a quantidade acumulada desse elemento nas raízes e na parte aérea foram pouco alterados. Algumas vezes as quantidades acumuladas foram, incoerentemente, maiores quando se aplicou o corretivo do que quando este não foi aplicado. A produção de material seco também foi pouco alterada pela aplicação do corretivo. Os teores e as quantidades acumuladas de $\mathrm{N}, \mathrm{P}$ e K nas raizes e na parte aérea das plantas, na maioria dos casos não foram influenciados significativamente pela aplicação do corretivo. Em algumas ocasiões, as quantidades acumuladas chegaram a ser maiores sem a adição do corretivo, do que com a sua aplicação.

Avaliando-se o efeito dos horizontes na ausência do corretivo, verificou-se que os teores de $\mathrm{Al}$ nas raizes foram superiores nas plantas cultivadas nas terras do horizonte B do que nas do horizonte A. Esse fato era esperado, pois o teor de alumínio no horizonte $\mathrm{B}\left(14,7 \mathrm{cmol}_{\mathrm{c}} \cdot \mathrm{dm}^{-3}\right)$ era muito superior ao do horizonte $\mathrm{A}\left(0,8 \mathrm{cmol}_{\mathrm{c}} \cdot \mathrm{dm}^{-3}\right)$. Contudo, em muitos casos, as plantas cultivadas nos horizontes $\mathrm{A}$ e $\mathrm{B}$ não diferiram entre si, quanto aos teores e as quantidades acumuladas de nutrientes, nem quanto à produção de material seco; também não 
foram notados quaisquer sintomas de toxicidade ao $\mathrm{Al}$ nas raizes, enquanto a parte aérea mostrava bom desenvolvimento vegetativo.

Análises posteriores, realizadas na solução do solo, extraída de amostras incubadas com diferentes doses do corretivo, revelaram que o solo estudado, mesmo com níveis elevados de $\mathrm{Al}$ trocável, possui teores muito baixos desse metal na solução. Esse fato explicaria a ausência de sintomas de toxicidade ao aluminio nas plantas e a pouca influência desse elemento sobre o desenvolvimento e a absorção de nutrientes pelos vegetais. Para esse solo, portanto, o teor de $\mathrm{Al}$ trocável extraído com solução de $\mathrm{KCl} 1 \mathrm{~N}$ não constitui um indice adequado para estimar a toxicidade desse elemento. 


\title{
EXCHANGEABLE ALUMINUM OF A RED-YELLOW PODZOLIC SOIL OF THE STATE OF ACRE (BRAZIL) AND ITS ABSORPTION BY
}

\section{PLANTS}

\author{
Author: JOSÉ RAIMUNDO NATIVIDADE FERREIRA GAMA \\ Adviser: PROF. DR. JORGE DE CASTRO KIEHL
}

\section{SUMMARY}

The Red-Yellow Podzolic soil, one of more representative soils of the Acre State, Brazil, differs from other podzolic soils, by the presence of volcanic materials, amorphous alophanes higher than 17\%, and high calcium, magnesium and aluminum exchangeable contents. Although the aluminum contents exceeds $13 \mathrm{cmol}_{\mathrm{c}} \cdot \mathrm{dm}^{-3}$ in certain areas, plants cultivated in this soil do not present toxicity symptoms or reduction of yield. In the work the author investigated the cause of the absence of these toxicity symptoms

In one experiment, samples from the $\mathrm{A}$ and $\mathrm{B}$ horizons were incubated for 7 and 14 days with different rates of calcium carbonate. The resulting $\mathrm{pH}$ was determined in water and in $\mathrm{CaCl}_{2}$, as well as the exchangeable aluminum extracted with $1 \mathrm{~N} \mathrm{KCl}$ and quantified by titration with $0,025 \mathrm{~N} \mathrm{NaOH}$ or by atomic absorption spectrophotometry. In a second experiment, four species or cultivars (rice, cv. "Fernandes" and IAC 1131; bean, cv. "Rosinha", and maize, cv. C511-A) were grown in pots containing $3 \mathrm{~kg}$ of soil previously treated or not with lime in order to increase the base saturation to $80 \%$. After 60 days, roots and tops were analyzed for $\mathrm{Al}, \mathrm{N}, \mathrm{P}$ and $\mathrm{K}$.

The amount of exchangeable aluminum of the soil samples incubated with lime, as determined by titration with $\mathrm{NaOH}$, showed to be coherent with the amounts obtained by atomic absorption spectrophotometry. 
Despite of the significant reduction of the amount of soil exchangeable $\mathrm{Al}$ due to lime application, the content and the total amount of this element in the plant roots and tops were only slightly changed. In some cases the total amount in the plant were incoherently higher when lime was applied than when it was not. The yield of dry matter was also only slightly influenced by the lime application. In most of the cases the content and the total amount of N, P and $\mathrm{K}$ in the plant roots and tops were not significantly altered by the applied lime. Occasionally, the total amounts of these nutrients in the plants grown in the nonlimed samples were higher than those found when the soil was limed.

Regarding the effect of the soil horizons in the absence of applied lime, it was noted that the $\mathrm{Al}$ contents in the roots were higher in plants grown in samples from the B horizon than in those grown in samples from the A horizon. This fact was expected since the exchangeable $\mathrm{Al}$ in the $\mathrm{B}$ horizon $\left(14,7 \mathrm{cmol}_{\mathrm{c}}\right.$ . $\left.\mathrm{dm}^{-3}\right)$ was far superior to that in the A horizon $\left(0.8 \mathrm{cmol}_{\mathrm{c}} \cdot \mathrm{dm}^{-3}\right)$. However, in many cases the yield of dry matter and the content and total amount of nutrients in the plants grown in the A horizon were not different from those cultivated in the B horizon; in addition, the roots showed no aluminum toxicity symptoms, and the tops presented a normal vegetative development

Further analysis, performed in the soil solution extracted from samples previously incubated with different rates of lime, revealed that the studied soil, although having very high levels of exchangeable $\mathrm{Al}$, bears a very low concentration of aluminum in solution. This fact would explain the absence of aluminum toxicity symptoms and the low influence of this element on the nutrient absorption and the plant development. Therefore, for this soil the exchangeable $\mathrm{Al}$ content extracted with $1 \mathrm{~N} \mathrm{KCl}$ is not an adequate index for predicting aluminum toxicity to plants. 


\section{1 - INTRODUÇÃO}

Na região amazônica, a significativa diversidade de solos torna evidente a necessidade de busca de propriedades genéticas que permitam o estabelecimento de características diferenciais para a classificação dos solos, determinação de sua potencialidade agrícola e distribuição geográfica.

Uma das classes de solos classificada como Podzólico Vermelho-Amarelo que, tem uma expressiva distribuição geográfica, apresenta algumas características diferentes dos demais podzólicos da Amazônia. No Estado do Acre esse solo encontra-se localizado particularmente nos municípios de Rio Branco e Sena Madureira.

Embora esse Podzólico já tenha sido estudado quanto à sua mineralogia, uso racional e classificação, os resultados obtidos ainda apresentam interrogações quanto as suas propriedades físicas, químicas e mineralógicas, mostrando a necessidade de outros estudos.

Dentre as características que os distinguem dos demais solos desta classe, destaca-se a presença de sedimentos de origem vulcânica oriundos dos Andes. São solos que possuem altos teores de 
minerais primários, e alta atividade coloidal decorrente da presença dominante de minerais de argila 2:1 além de CTC elevada, presença de vidros vulcânicos na fração areia fina, teor de material amorfo alofânico superior a $17 \%$, teores de silte elevados em relevo suave ondulado e ondulado. Eles podem ser eutróficos e distróficos com argila de atividade alta, e teores altos de cálcio, magnésio e aluminio, simultaneamente.

O alumínio trocável, além de ser uma das principais fontes de acidez extraível em solos tropicais, exerce efeitos tóxicos sobre o crescimento dos vegetais, notadamente sobre o sistema radicular, além de ter influência sobre a absorção e translocação de fósforo, cálcio e magnésio na planta e sobre a fixação de $\mathrm{P}$ no solo. Culturas introduzidas nesse solo, todavia, não tem apresentado sintomas de toxidade, mostrando, ao contrário, desenvolvimento vegetativo normal e taxas de produtividade variando de média a alta.

Em face dessas observações, o presente trabalho foi realizado com os seguintes objetivos:

- Investigar a causa da ausência de sintomas de toxicidade ao alumínio em plantas cultivadas em um solo Podzólico Vermelho-Amarelo do Acre, com elevados teores desse elemento; e 
- Verificar se o teor de alumínio trocável extraído com solução de $\mathrm{KCl}$ $1 \mathrm{~N}$, constitui um indice adequado para se estimar a toxicidade desse elemento às plantas. 


\section{REVISÃO DE LITERATURA}

\subsection{Alumínio no solo}

A maioria dos solos das regiões tropicais e subtropicais úmidas apresentam em função de sua história pedogenética, teores relativamente elevados de alumínio permutável, limitantes para o crescimento vegetal, associados a baixos valores de $\mathrm{pH}$ (OLMOS \& CAMARGO, 1976).

A da química do alumínio em solução têm sido intensamente estudada nas últimas décadas, apesar dos conceitos modernos sobre acidez do solo terem sido desenvolvidos no início da década de 50. Uma revisão sobre a evolução de tais conhecimentos foi apresentada por COLEMAN \& TOMAS (1967), os quais tem sido subseqüentemente reproduzidos por diversos autores como FOY (1974a) e HELYAR (1978).

A quantidade de alumínio presente na solução do solo depende de dois fatores: da quantidade e espécie do composto de alumínio no solo e da reação do meio (MAGISTAD, 1925). O alumínio 
é um cátion trivalente normalmente associado a seis moléculas de água, e que pode ser representado pelo monômero $\mathrm{Al}\left(\mathrm{H}_{2} \mathrm{O}\right)_{6}^{3+}$.

De acordo com FOY (1974), a solubilidade do alumínio e sua toxicidade para as plantas são afetadas por vários fatores, tais como o $\mathrm{pH}$ do solo, o conteúdo de matéria orgânica, as características mineralógicas da fração argila e a concentração de outros cátions na solução do solo.

Existem três faixas definidas de $\mathrm{pH}$ com respeito à estabilidade do alumínio em solução aquosa. Acima de $\mathrm{pH} 7,5$ a solubilidade aumenta marcadamente, aparecendo alumínio na forma aniônica $\mathrm{Al}(\mathrm{OH})_{4}^{-}$. Entre $\mathrm{pH}$ 7,5 e 5,2 há pouca ou quase nenhuma ocorrência de alumínio solúvel (corresponde à faixa de sua precipitação como $\left.\mathrm{Al}(\mathrm{OH})_{3} \cdot 3 \mathrm{H}_{2} \mathrm{O}\right)$. Finalmente, na faixa de $\mathrm{pH}$ correspondida entre $\mathrm{pH} \quad 4$ e 5 , a sua solubilidade novamente aumenta marcadamente.(MAGISTADE, 1925). Segundo McLEAN (1965), à medida que diminui a acidez, o monômero sofre hidrólise, havendo liberação de íons $\mathrm{H}^{+}$para o meio e permanencia de $\mathrm{OH}^{-}$junto ao alumínio.

De modo geral, a toxicidade ao alumínio não está presente em solos que apresentam $\mathrm{pH}$ superior a 5,5, mas é comum a valores menores, pois a faixa de $\mathrm{pH}$ de maior importância do ponto de vista de toxicidade em solos ácidos é justamente de 4,0 a 5,5. A 
toxicidade de aluminio é especificamente severa em solos com $\mathrm{pH}$ abaixo de 5,0, mas pode ocorrer em solos com valor de $\mathrm{pH}$ até 5,5 (MESQUITA FILHO \& SOUZA, 1986).

CAMARGO \& FURLANI (1989), relatam que a liberação de aluminio $\left(\mathrm{Al}^{3+}\right)$ para a solução do solo ocorre em função da ação de prótons $\mathrm{H}^{+}$que atuam na camada octaedral da argila, os quais substituem o $\mathrm{Al}^{3+}$ e, algumas vezes, o $\mathrm{Mg}^{2+}$. É estes, por sua vez, quando liberados, são adsorvidos pelos contra-ions do mineral de argila, originando um sistema $\mathrm{H}-\mathrm{Al}$-argila.

O efeito da presença de argila predominante no solo sobre o grau de hidrólise do alumínio é contraditório. Observações de RAGLAND \& COLEMAN (1960) evidenciaram um aumento no grau de hidrólise, enquanto FRINK \& PEECH ((1963), estudando a seletividade da absorção do $\mathrm{Al}^{3+}, \mathrm{Al}(\mathrm{OH})^{2+}$ e $\mathrm{H}^{+}$, e a relação $\mathrm{H}^{+} / \mathrm{Al}^{3+}$ da suspensão de argila, verificaram uma redução no grau de hidrólise devida à presença desse mineral.

O aumento do teor de matéria orgânica no solo proporciona um aumento da taxa de hidrólise, devido a reação de seus produtos com os grupos carboxílicos (THOMAS \& HARGROVE, 1984). De acordo com PAVAN \& BINGHAN (1982), os ions considerados como responsáveis pela toxicidade nas plantas são os monômeros $\mathrm{Al}^{3+}$ e $\mathrm{Al}(\mathrm{OH})^{2+}$, presentes na faixa de $\mathrm{pH}$ entre 4,0 e 5,0. 
Estudos realizados através do projeto RADAMBRASIL (BRASIL, 1976) em solos do Estado do Acre evidenciaram quantidades de cálcio, magnésio e alumínio trocáveis simultaneamente elevadas tanto no horizonte A como no horizonte B. Mais tarde, esses mesmos solos foram também estudados por GAMA (1986), que encontrou, no horizonte $\mathrm{A}$, valores de cálcio e magnésio acima de $8 \mathrm{cmol}_{\mathrm{c}} / \mathrm{kg}$, bem como valores de $\mathrm{Al}^{3+}$ superiores a $2 \mathrm{cmol}_{\mathrm{c}} / \mathrm{kg}$. No horizonte $\mathrm{B}$ os teores de aluminio estavam acima de $8,8 \mathrm{cmol}_{\mathrm{c}} / \mathrm{kg}$ de TFSA, atingindo valores de até $13,7 \mathrm{cmol}_{\mathrm{c}} / \mathrm{kg}$ de TFSA, enquanto os teores de cálcio e magnésio eram superiores a $9 \mathrm{cmol}_{\mathrm{c}} / \mathrm{kg}$.

\subsection{Toxicidade de alumínio e efeito benéfico nos}

\section{vegetais}

Na maioria das espécies vegetais o aluminio está presente em quantidades variáveis na matéria seca (MAGISTAD, 1925). Sabe-se que o aluminio absorvido pelas plantas é largamente precipitado na interface solo-raiz (FOY, 1974a).

Segundo ANDREW et al. (1973), o aluminio tem pouca mobilidade nas plantas, concentrando-se mais nas raizes do que na parte aérea, sendo que os polimeros hidrogênio-Al podem ser mais 
tóxicos para as plantas do que os ions de monômero-Al (WAGA TSUMA \& EZOE, 1985).

Os conhecimentos contidos na literatura especializada referente à toxicidade do alumínio em plantas tem sido revisados por inúmeros autores (FOY et al., 1978; ROY et al., 1988; CAMBRAIA, 1989; FURLANI, 1989; FOY, 1992 e FAGERIA et al., 1988). Em escala mundial, os solos ácidos das regiões tropicais representam a maior restrição em proporcionar altos rendimentos das culturas devido à toxicidade ao alumínio e ao manganês, particularmente em áreas submetidas à condições redutoras (MENGEL \& KIRBY, 1987).

O alumínio trocável, quando ocorre em proporções elevadas no solo, atua principalmente no sistema radicular, interferindo nas reações energéticas e na absorção e transporte de água e nutrientes (FOY, 1966 e 1992), ao mesmo tempo em que regula a deposição de polissacarídeos nas paredes celulares (FOY, 1973 e 1974a). De acordo com ROY et al. (1988), a elongação das raizes fica impedida devido à redução da atividade mitótica, provocada pelo alumínio, com subseqüente aumento da susceptibilidade da planta à seca. Do mesmo modo, MALAVOLTA (1980) afirma que a região meristemática da ponta da raiz mostra um número anormalmente alto de células com dois núcleos, o que indica paralização do processo de divisão celular. 
De acordo com MATSUMOTO et al. (1977), o alumínio pode afetar o crescimento celular; mas, a possível associação do alumínio com pectinas, produzindo ligações cruzadas de pectinas com diminuição da parede celular, parece não ocorrer, uma vez que tem sido demonstrado que a maior parte do alumínio precipitado nas raízes não está associada com pectinas ou ácidos urônicos.

A raiz primária pode elongar-se de forma aparentemente normal, em baixas concentrações de alumínio, e o crescimento das raízes laterais inibido, dando aparência típica de raiz atrofiada. No início, o desenvolvimento é normal, mas é interrompido quando a endoderme da raiz é atingida (RORISON, 1958; REES \& SIDRAK, 1961).

As raízes primárias ficam atrofiadas, curtas e grossas sob o efeito de níveis elevados de alumínio. Os sintomas na parte aérea de modo geral são difíceis de serem distinguidos e, nessas condições, as taxas de crescimento são baixas e as folhas tornam-se pequenas e apresentando com coloração verde escura e púrpura (JACKSON, 1967).

Com respeito aos efeitos da toxicidade do alumínio sobre o crescimento das plantas superiores, é dada grande ênfase na literatura. Contudo, diversas considerações são feitas também no tocante aos efeitos benéficos do alumínio no crescimento das plantas, particularmente quando aplicado ao meio de cultura em baixas 
concentrações (HACKETT, 1962 e 1965; CLARKSON, 1966b; SALISBURY \& ROSS, 1969, MULLITTE, 1975).

De forma similar à toxicidade, os efeitos benéficos do alumínio variam entre espécies e entre cultivares de uma mesma espécie. De acordo com FOY (1983), os mecanismos da ação estimulada carecem de melhores estudos. São muitas as evidências de que o alumínio estimula diretamente o crescimento das plantas. Todavia, REES \& SIDRAK (1961) e FOY (1974) relatam que, apesar desses efeitos estimulantes, o papel do alumínio na fisiologia das plantas continua obscuro.

${ }^{1}$ Carvalho et al. citados por BUENO (1987), afirma que a presença do alumínio é capaz de estimular o crescimento em altura e a produção de material seco nas diversas partes da planta, em dosagem de até $20 \mathrm{cmol}_{\mathrm{c}} \cdot \mathrm{dm}^{-3}$ de alumínio em solução nutritiva. Esses dados são confirmados por BUENO (1987) cujas conclusões sofre o efeito de toxicidade ao alumínio no cresccimento da seringueira só é verificado em concentrações superiores a $15 \mathrm{cmol}_{\mathrm{c}} \mathrm{dm}^{-3}$.

GRIME \& RODGSON (1969) afirmaram que os efeitos benéficos do alumínio no crescimento da espécie Scabiosa columbreara são devidos a um aumento na utilização do ferro, resultante da substituição do ferro pelo alumínio nos sítios de troca da raiz.

${ }^{1}$ CARVALHO, J.G. de: VIEGAS, I.J.M.; BUENO, N.; HAAG, H.P. Efeito do alumínio sobre o desenvolvimento, absorção e translocação de nutrientes pela seringueira (Hevea brasiliensis) em solução nutritiva. (em preparação). 
Outra explicação é sugerida por CLARKSON (1966b) para o efeito benéfico do alumínio: quando este está ausente na solução nutritiva, é concebível que ocorra um mecanismo de ligação, provocando um aprisionamento de um ou mais nutrientes cationicos e ocasionando deficiência destes para o crescimento das plantas; contudo, se o alumínio estiver presente, este é "aprisionado", provocando uma redução de outros cátions. Esse "aprisionamento" está relacionado com a competição entre o alumínio e os demais nutrientes catiônicos pelos sítios das raízes, segundo LEE (1971).

Estudos que confirmam esses fatos foram efetuados por RASMUSSEN (1968) e MATSUMOTO et al. (1976), os quais mostraram detalhadamente a distribuição do alumínio nas raízes de milho e ervilha, respectivamente. Ambos estudos esclarecem que um padrão duplo de distribuição de alumínio se verifica nos tecidos radiculares, onde parte se liga extracelularmente ao nível de parede celular, e parte atravessa a plasmalema, penetrando intracelularmente.

Nos vegetais, a parte mais sensível ao excesso de alumínio, em termos morfológicos, é o sistema radicular, cujas raízes se apresentam curtas, grossas e frágeis, com ápices espessos e coloração marron. Ocorre formação de raízes laterais cujo crescimento também é reduzido As altas concentrações de alumínio afetam severamente as plantas, afetam as divisões celulares das raízes, diminuem a intensidade 
da respiração e interferem na absorção, transporte e metabolismo de vários elementos (FOY, 1974a).

LEVAN (1945) observou anormalidades severas na divisão celular de raízes de cebola sob altos teores de alumínio, incluindo a formação de cromossomos na anáfase. HUCK (1972) observou um desarranjo de células no periciclo e uma alta freqüência de células binucleadas nas raizes de algodoeiro quando expostas por 12 horas a uma concentração de 1 ppm de alumínio sob pH 4,3. Em razão dessa anomalia, houve formação de um sistema radicular morfologicamente anormal, com raízes laterais ausentes ou extremamente curtas, de diâmetros semelhantes aos das raizes principais, desenvolvidas próximo aos meristemas apicais.

Os sintomas de toxicidade comumente descritos referemse ao menor desenvolvimento da parte aérea e ao crescimento reduzido do sistema radicular, justamente em decorrência da inibição da divisão celular (CLARKSON, 1965).

ADAMS \& LUND (1966), realizando estudos com a cultura do algodão, e PAVAN \& BINGHAN (1982), com a de café, creditaram a inibição do crescimento radicular, à presença de alumínio, medida pela atividade do íon ao invés de sua concentração no meio. Por outro lado, para a soja, BLAMEY et al. (1983) mostraram que é mais adequado explicar os efeitos tóxicos do ion através da soma das 
atividades das espécies monômeras de alumínio $\left(\mathrm{Al}^{3+}+\mathrm{Al}(\mathrm{OH})^{2+}+\right.$ $\left.\mathrm{Al}(\mathrm{OH})^{+}{ }_{2}+\mathrm{Al}(\mathrm{OH})_{3}+\mathrm{Al}\left(\mathrm{SO}_{4}\right)^{+}\right)$. PARKER et al. (1989) concluíram que as espécies e/ou variedades vegetais, bem como as condições experimentais condicionam as respostas fitotóxicas de espécies polinucleares de alumínio.

\subsection{Mecanismos de tolerância}

Espécies de plantas e cultivares de uma mesma espécie variam largamente quanto à tolerância ao alumínio. Os mecanismos de tolerância vegetal são calcados basicamente no mecanismo de exclusão e tolerância interna ao alumínio acumulado (FOY et al., 1978). Esse fato foi confirmado por FURLANI (1989), o qual apresenta uma classificação das causas de tolerância diferencial de plantas ao alumínio. FOY et al. (1967) relataram que muitos autores associam a tolerância diferencial ao alumínio à capacidade das plantas em absorver esse elemento.

FAGERIA \& ZIMMERMANN (1979), estudando diversos cultivares de arroz, concluiram que, a o se aumentar o pH da solução até cinco ou mais, reduzia-se também a solubilidade do alumínio e, conseqüentemente, eliminavam-se as diferenças de crescimento entre os cultivares sensíveis e tolerantes. Os mesmos autores concluem também, 
que a toxicidade do alumínio é um fator significante na redução do rendimento do arroz em solos ácidos.

PAVAM \& BINGHAM (1982), estudando a toxicidade do alumínio em cafeeiro, observaram que em diversas concentrações de alumínio na solução houve redução na produção, bem como diminuição no crescimento radicular, e que não houve produção, quando a concentração de alumínio excedeu $296 \mu \mathrm{mol} \mathrm{dm} \mathrm{dm}^{-3}$.

Diversos estudos comparativos têm atribuído a tolerância ao alumínio à maior habilidade da planta em absorver e em utilizar alguns nutrientes na presença desse elemento. A tolerância ao alumínio de alguns cultivares de trigo e cevada (FOY et al., 1967), de feijão (FOY et al., 1972) e de cevada (ARMINGER et al., 1968) parece estar relacionada com a habilidade da planta em absorver cálcio na presença de alumínio. Em milho (CLARK \& BROWN, 1974), a tolerância parece estar associada à habilidade de absorver e de utilizar o fósforo na presença de alumínio.

FAGERIA \& KLUTHCOUSKI (1980) classificaram algumas cultivares de arroz e feijão de acordo com o grau de tolerância à toxicidade de alumínio em: tolerantes, quando o comprimento relativo da raiz é maior que $60 \%$ do desenvolvimento; moderadamente tolerantes, quando está entre 45 e 60\%; moderadamente susceptíveis, 
quando o comprimento estiver entre 30 e $45 \%$ e susceptível, quando menor que $30 \%$.

FOY et al. (1975a), determinando limites de tolerância entre variedades de trigo e cevada, observaram acentuadas variações no crescimento da parte aérea das plantas e das raizes, ocasionadas pela toxicidade ao alumínio existente no solo onde foram plantadas. Todavia, atingiram o máximo de crescimento sem diferença significativa, quando foram adicionados $3.000 \mathrm{mg} / \mathrm{kI}$ de $\mathrm{CaCO}_{3} \mathrm{em}$ um solo com pH 5,8.

As cultivares de arroz IAC 1131 e Fernandes diferem largamente quanto à sensibilidade ao alumínio. Estudos de seleção feitos por FAGERIA \& ZIMMERMANN (1979) mostraram que resultados relacionados à altura da planta, matéria seca e comprimento de raizes diferiram muito quando os tratamentos com 40 e $60 \mathrm{ppm}$ de aluminio foram comparados com os de 0,10 e $20 \mathrm{ppm}$ de alumínio. A altura da planta ficou entre $45,12 \mathrm{~cm}$ e $35,25 \mathrm{~cm}$ sob as concentrações de 40 e 60 ppm de alumínio, respectivamente, contra alturas superiores a $59,12 \mathrm{~cm}$ verificadas sob concentrações de alumínio iguais ou inferiores a $20 \mathrm{ppm}$.

Os mesmos autores, determinaram o comprimento de raízes entre $16,25 \mathrm{~cm}$ e $14,12 \mathrm{~cm}$ para as mesmas concentrações de aluminio (40 e $60 \mathrm{ppm}$ ) e comprimento superior atingindo $20,62 \mathrm{~cm}$ 
para as outras concentrações. O material seco da parte aérea, para essas cultivares, ficou entre os extremos de 1,40 e 3,43 g/planta, e a da raiz entre 0,28 e $0,80 \mathrm{~g} / \mathrm{planta}$.

Algumas variedades de trigo, arroz e milho tolerantes ao alumínio, possuem a habilidade de elevar o $\mathrm{pH}$ da solução nutritiva, o que diminui a solubilidade do íon e, conseqüentemente, sua toxicidade (FOY et al., 1965a e 1967). Em contraste, as cultivares sensíveis das mesmas espécies diminuem ou não mudam o pH da solução. Tal habilidade está relacionada com a absorção diferencial de cátions e ânions (MUGWIRA et al., 1978).

Estudos efetuados por CALBO \& CAMBRAIA (1980) evidenciaram a existência de um mecanismo interno de desintoxicação em cultivares de sorgo que acumularam quantidades consideráveis de alumínio no protoplasma das células da raiz. Outras espécies como chá, arroz e trigo acumulam grande teor do íon alumínio na sua parte aérea (ROY et al. 1988).

Outra hipótese para explicar a tolerância diferencial entre cultivares é a existência de mecanismos de quelatação do alumínio através dos ácidos orgânicos e fenóis. JOHNSON \& JACKSON (1964) verificaram que o íon $\mathrm{Al}^{3+}$ complexado com EDTA não promovia redução da absorção de cálcio pelas raízes de cevada, ocorrendo o inverso quando as plantas foram tratadas com $\mathrm{AlCl}_{3}$. 
O efeito competitivo entre o alumínio e o cálcio pelos sítios ativos de ligação externa para a cultura do sorgo, é defendido por KINRAIDE \& PARQUER (1987). Este fato é reforçado por FOY et al. (1978) de modo conceitual, que a tolerância ao alumínio pode estar associada à capacidade da planta em resistir à deficiência de cálcio. 


\section{3 - MATERIAL E MÉTODOS}

\subsection{Solo}

O solo estudado neste trabalho localiza-se no Estado do Acre, particularmente nos municípios de Rio Branco e Sena Madureira, e foi classificado como Podzólico Vermelho-Amarelo. É um solo de textura muito argilosa, argila de atividade alta e apresenta como características marcantes os elevados teores de cálcio, magnésio e alumínio trocáveis, simultaneamente. Os teores de alumínio trocável nesse solos superam $13 \mathrm{cmol}_{\mathrm{c}} / \mathrm{kg}$ (BRASIL, 1976 e GAMA, 1986).

Amostras dos horizontes A e B foram coletadas a $11 \mathrm{~km}$ do entroncamento no sentido Sena Madureira-Rio Purús, no Estado do Acre, ao lado direito da estrada BR 364, em local distando 50 metros da rodovia. Foram ensacadas, destorroadas e passadas em peneira de $2 \mathrm{~mm}$. Essas amostras foram submetidas a análises físicas e químicas de rotina, de conformidade com as normas contidas no Manual de Métodos de Análise de 
Solos (EMBRAPA, 1979). Os resultados das análises acham-se nas Tabelas 1, 2 e 3.

\subsection{Incubação do solo com $\mathrm{CaCO}_{3}$}

Inicialmente foi realizado no laboratório, estudo do comportamento do alumínio trocável do solo em função do pH. Para tanto, amostras dos horizontes A e B foram tratadas com doses crescentes de carbonato de cálcio $(0,0 ; 0,1 ; 0,2 ; 0,4$ e $0,6 \mathrm{~g} / 100 \mathrm{~g}$ de terra para o horizonte A e 0,$0 ; 0,2 ; 0,4 ; 0,6$ e $0,8 \mathrm{~g} / 100$ de terra para o horizonte B), observando-se um número de três repetições. As amostras foram umedecidas e incubadas. No 70 e no $14^{\circ}$ dia, sub-amostras foram coletadas para determinação do $\mathrm{pH}$ em água e em $\mathrm{CaCl}_{2}$ 0,01M, bem como do teor de alumínio trocável. Este, foi extraído com solução de $\mathrm{KCl} 1 \mathrm{~N}$ e determinado de duas maneiras: por titulação com $\mathrm{NaOH} \quad 0,025 \mathrm{~N}$ e por leitura em espectrofotômetro de absorção atômica (EMBRAPA, 1979).

Os resultados foram submetidos à análise de variância, sendo as médias comparadas através do teste de Tukey ao nível de significância de 5\% de probabilidade. Efetuaram-se análises de regressão para avaliar o efeito de doses de carbonato de cálcio no $\mathrm{pH}$. 
Tabela 1. Propriedades físicas nos horizontes A e B de um solo Podzólico Vermelho-Amarelo, localizado no município de Sena Madureira-Acre.

\begin{tabular}{|c|c|c|c|c|c|c|c|c|}
\hline \multicolumn{2}{|c|}{ Horizonte } & \multicolumn{4}{|c|}{ Composigāo granulométrica } & \multirow{3}{*}{$\begin{array}{l}\text { Argila } \\
\text { dispersa } \\
\text { em água }\end{array}$} & \multirow{3}{*}{$\begin{array}{c}\text { Graú } \\
\text { de } \\
\text { noculação }\end{array}$} & \multirow{3}{*}{$\begin{array}{l}\% \text { Silte } \\
\% \text { argila }\end{array}$} \\
\hline \multirow[t]{2}{*}{ Símbolo } & \multirow{2}{*}{$\frac{\text { Prof }}{(\mathrm{cm})}$} & \multicolumn{2}{|c|}{ Areia } & \multirow[t]{2}{*}{ Silte } & \multirow[t]{2}{*}{ Argila } & & & \\
\hline & & grossa & fina & & & & & \\
\hline & & & & & $\%$ & & & \\
\hline A & $0-23$ & 1 & 1 & 65 & 33 & 23 & 30 & 1,97 \\
\hline B & $23-52$ & 14 & 13 & 24 & 49 & 0 & 100 & 0,49 \\
\hline
\end{tabular}

Tabela 2. Propriedades químicas nos horizontes A e B de um solo Podzólico Vermelho-Amarelo, localizado no município de Sena Madureira-Acre

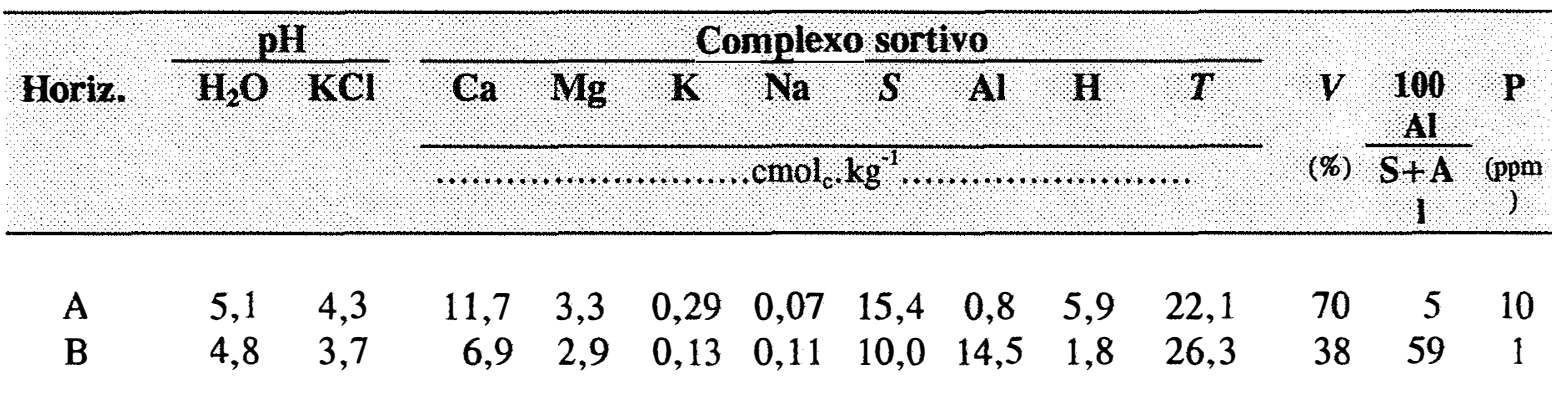

Tabela 3. Teores de carbono orgânico, nitrogênio total e de elementos obtidos por ataque com $\mathrm{H}_{2} \mathrm{SO}_{4}, \mathrm{NaOH}$ e relações molares nos horizontes $\mathrm{A}$ e $\mathrm{B}$ de um solo Podzólico Vermelho-Amarelo, localizado no município de Sena Madureira-Acre.

\begin{tabular}{|c|c|c|c|c|c|c|c|c|c|c|}
\hline \multirow{3}{*}{ Horiz. } & \multirow{3}{*}{$\frac{\mathrm{C}}{1}$} & \multirow{3}{*}{$\frac{\mathrm{N}}{2}$} & \multirow{3}{*}{$\mathrm{C} / \mathrm{N}$} & \multicolumn{4}{|c|}{ Ataque por } & \multirow{3}{*}{$\begin{array}{l}\frac{\mathrm{SiO}_{2}}{\mathrm{Al}_{2} \mathrm{O}_{3}} \\
\text { (Ki) }\end{array}$} & \multirow{3}{*}{$\begin{array}{l}\mathrm{SiO}_{2} \\
\mathrm{R}_{2} \mathrm{O}_{3} \\
(\mathbf{k r})\end{array}$} & \multirow{3}{*}{$\frac{\mathrm{Al}_{2} \mathrm{O}_{3}}{\mathrm{Fe}_{2} \mathrm{O}_{3}}$} \\
\hline & & & & \multicolumn{2}{|c|}{$\mathrm{H}_{2} \mathrm{SO}_{4}$} & \multicolumn{2}{|c|}{$\mathrm{NaOH}$} & & & \\
\hline & & & & $\mathrm{SiO}_{2}$ & $\mathrm{Al}_{2} \mathbf{O}_{3}$ & $\mathrm{Fe}_{2} \mathrm{O}_{3}$ & $\mathrm{TiO}_{2}$ & & & \\
\hline A & 1,78 & 0,18 & 10 & 17,7 & 8,1 & 13,7 & 0,44 & 3,71 & 2,87 & 3,44 \\
\hline B & 0,57 & 0,11 & 5 & 24,0 & 12,6 & 5,4 & 0,47 & 3,24 & 2,54 & 3,66 \\
\hline
\end{tabular}




\subsection{Experimento em casa-de-vegetação}

O experimento foi instalado em casa de vegetação, localizada na Escola Superior de Agronomia "Luiz de Queiroz", em Piracicaba,em vasos de cerâmica contendo $3 \mathrm{~kg}$ de terra cada, provenientes dos horizontes $\mathrm{A}$ e B. O delineamento experimental foi inteiramente casualizado em esquema fatorial envolvendo quatro cultivares e/ou espécies de planta (os cultivares de arroz, "Fernandes" tolerância alta ao alumínio e IAC 1131 tolerância baixa ao alumínio; doravante denominadas "arroz 1" e "arroz 2"; cultivar "Rosinha,"de feijão tolerância média ao alumínio e cultivar C511-A de milho altamente sensivel ao alumínio), dois horizontes do solo selecionado (A e B) e duas doses de uma mistura contendo $4 / 5$ de carbonato de cálcio e 1/5 de carbonato de magnésio (sem carbonato e com carbonato em doses calculadas para elevar a percentagem de saturação por bases a $80 \%$; essas doses corresponderam a 1,58 e 7,89 $\mathrm{cmol}_{\mathrm{c}} / \mathrm{kg}$ para as amostras dos horizontes A e B, respectivamente), totalizando 16 tratamentos, com três repetições , resultando em 48 parcelas. A incubação do solo com calcário foi efetuada durante 15 dias.

A adubação foi efetuada com NPK em todos os vasos, aplicando-se nas amostras do horizonte A, respectivamente 150,100 e 100 ppm de N, P e K baseada nas análises de terras e nas amostras do horizonte $\mathrm{B}$, respectivamente, 150,300 e $200 \mathrm{ppm}$ de $\mathrm{N}, \mathrm{P}$ e $\mathrm{K}$, nas formas de uréia, 
superfosfato simples e cloreto de potássio. As sementes das cultivares de arroz, milho e feijão foram plantadas diretamente nas terras dos vasos. Oito a dez dias depois da germinação foi efetuado o desbaste, deixando-se dez plantas de cada cultivar de arroz e cinco plantas de cada cultivar de milho e feijão. Durante o crescimento foi efetuado o controle visual de pragas não havendo nenhum ataque das mesmas.

Ao final de 60 dias colheu a parte aérea das plantas cortando-se rente ao solo. As raízes foram separadas da terra por meio de jato d'àgua, medindo-se sua extensão. A seguir, parte aérea e raízes foram secadas em estufa a $70^{\circ} \mathrm{C}$ até peso constante, moídas, pesadas e submetidas às determinações de alumínio, nitrogênio, fósforo e potássio de acordo com as normas citadas por MALAVOLTA et al. (1989). Os resultados foram avaliados estatisticamente através de análises de variância e comparação de médias pelo teste de Tukey ao nível de 5\% (GOMES, 1960).

Os parâmetros utilizados para avaliar os tratamentos foram: produção de matéria seca e concentração e acúmulo de alumínio, nitrogênio, fósforo e potássio nas raízes e na parte aérea das plantas.

\section{4. Obtenção e análise do extrato de saturação}

Nas amostras de terra dos horizontes A e B, executou-se o extrato de saturação utilizando-se a metodologia descrita por RHOADES 
(1982). Pesaram-se $100 \mathrm{~g}$ de terra em béquer de plástico de $500 \mathrm{~mL}$ e adicionou-se água destilada paulatinamente, homogeneizando-se a terra com uma espátula, até a formação de uma pasta saturada. Na saturação, a pasta adquire as seguintes características: (1) reflete a luz incidente; (2) flui livremente quando o béquer é virado; e (3) escorrega livremente de uma espátula limpa, sem sujá-la (exceto para solos de textura muito argilosa). Em seguida, o béquer foi coberto e a pasta deixada em repouso por uma noite. Os critérios de saturação foram checados novamente no dia seguinte, observandose se havia água livre na superficie (supersaturação) ou se a pasta havia perdido o seu brilho (subsaturação); quando isso aconteceu, acrescentou-se um pouco mais de terra ou de água, conforme o caso. Passadas outras duas horas de repouso, a pasta saturada foi submetida à centrífugação. Na solução sobrenadante determinou-se o teor de alumínio por titulação com $\mathrm{NaOH} 0,025$ $\mathrm{N}$ e por leitura em espectrofotômetro de absorção atômica (EMBRAPA, 1979). 


\section{4 - RESULTADOS E DISCUSSÃO}

\subsection{Alterações do $\mathrm{pH}$ e do teor de alumínio trocável em amostras de solo incubadas com $\mathrm{CaCO}_{3}$, avaliadas por diferentes métodos}

Os valores de $\mathrm{pH}\left(\mathrm{H}_{2} \mathrm{O}\right.$ e $\left.\mathrm{CaCl}_{2}\right)$ determinados após 7 e 14 dias de incubação do solo com as doses de $\mathrm{CaCO}_{3}$, são apresentados na Tabela 4 . A análise estatística não revelou diferenças significativas entre os valores determinados aos 7 e 14 dias. $\mathrm{O}$ estudo de regressão polinomial mostrou que a variação do $\mathrm{pH}$ com as doses de corretivo foi mais acentuada no horizonte $\mathrm{A}$ (Figura 1) que no horizonte B (Figura 2), indicando a existência de forte tamponamento nesta última camada. A análise do solo (Tabela 2) mostra que o elevado tamponamento no horizonte $\mathrm{B}$ deve-se à maior acidez potencial $(\mathrm{H}$ + Al) e que esta, é em grande parte, causada pela acentuada presença de $\mathrm{Al}$ trocável no solo. 
Tabela 4. Valores médios de $\mathrm{pH}$ em $\mathrm{H}_{2} \mathrm{O}$ e $\mathrm{CaCl}_{2}$ 0,01M após 7 e 14 dias de incubação comdiferentes doses de $\mathrm{CaCO}_{3} \mathrm{em}$ amostras dos horizontes A e B de um Podzólico Vermelho-Amarelo do município de Sena Madureira Estado do Acre.

\begin{tabular}{|c|c|c|c|c|c|}
\hline \multirow{3}{*}{ Horizonte } & \multirow{3}{*}{$\begin{array}{c}\text { Dose de } \\
\text { CaC D } \\
(\mathrm{g})\end{array}$} & \multicolumn{2}{|c|}{$\mathrm{pH} \mathrm{H}_{2} \mathrm{O}$} & \multicolumn{2}{|c|}{$\mathrm{pH} \mathrm{CaCl}_{2}$} \\
\hline & & 7 & 14 & 7 & 14 \\
\hline & & \multicolumn{2}{|c|}{ dias } & \multicolumn{2}{|c|}{ dias } \\
\hline & 0,0 & 5,4 & 5,5 & 4,5 & 4,4 \\
\hline & 0,1 & 6,0 & 5,9 & 5,1 & 5,0 \\
\hline \multirow[t]{5}{*}{$\mathrm{A}$} & 0,2 & 6,8 & 6,3 & 6,1 & 5,7 \\
\hline & 0,4 & 7,8 & 7,4 & 7,3 & 6,8 \\
\hline & 0,6 & 8,0 & 7,8 & 7,4 & 7,4 \\
\hline & 0,0 & 4,9 & 5,3 & 3,7 & 3,7 \\
\hline & 0,2 & 5,0 & 5,4 & 4,1 & 4,0 \\
\hline \multirow[t]{3}{*}{ B } & 0,4 & 5,2 & 5,4 & 4,1 & 4,2 \\
\hline & 0,6 & 5,3 & 5,5 & 4,3 & 4,5 \\
\hline & 0,8 & 5,6 & 5,6 & 4,5 & 5,3 \\
\hline
\end{tabular}



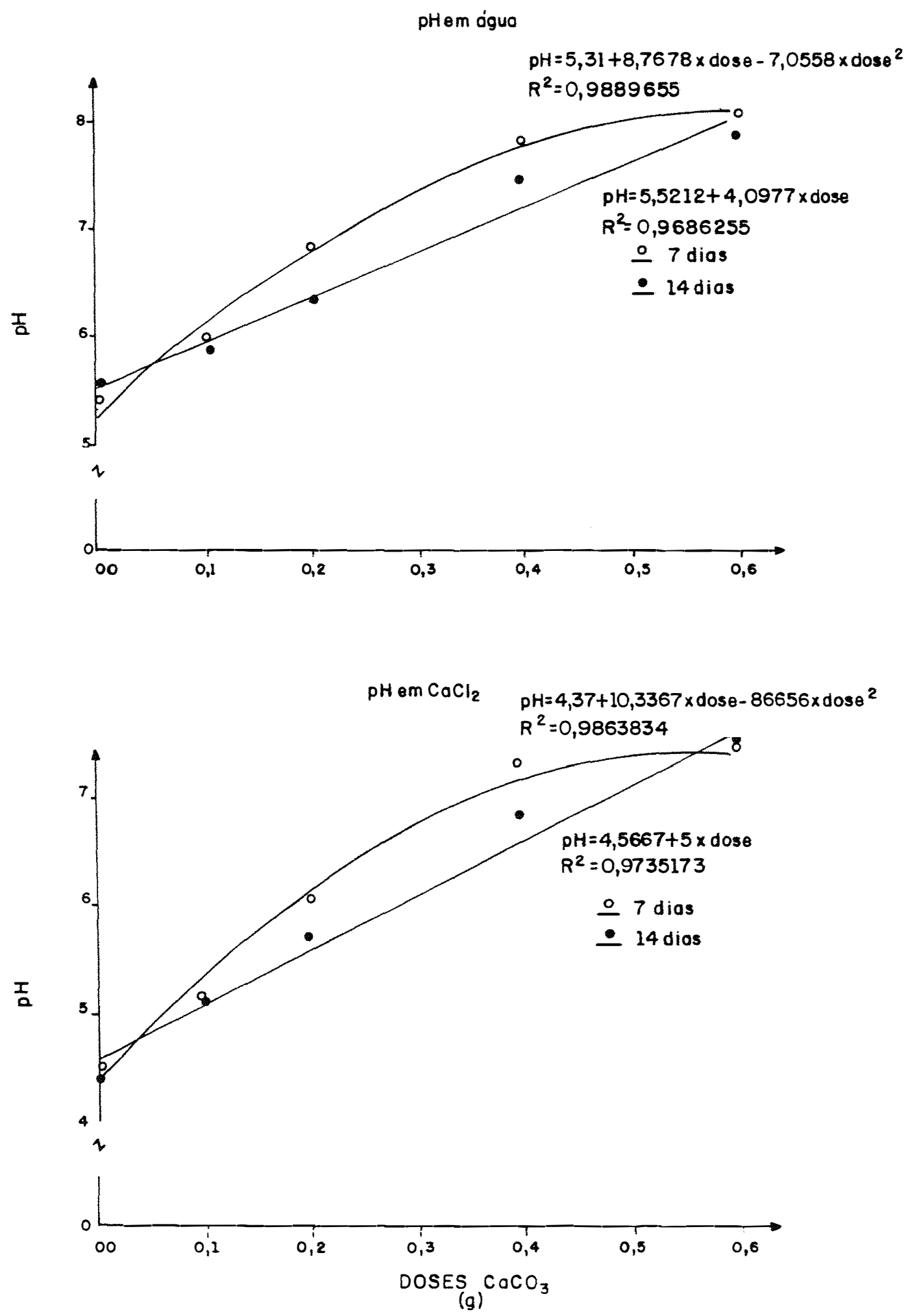

Figura 1. Variação do $\mathrm{pH}$ em água e $\mathrm{CaCl}_{2}, 0,01 \mathrm{M}$ de amostras de horizonte $\mathrm{A}$ do solo Podzólico Vermelho-Amarelo do Estado do Acre, após 7 e 14 dias de adição de diferentes doses de $\mathrm{CaCO}_{3}$. 
pHem $\mathrm{H}_{2} \mathrm{O}$

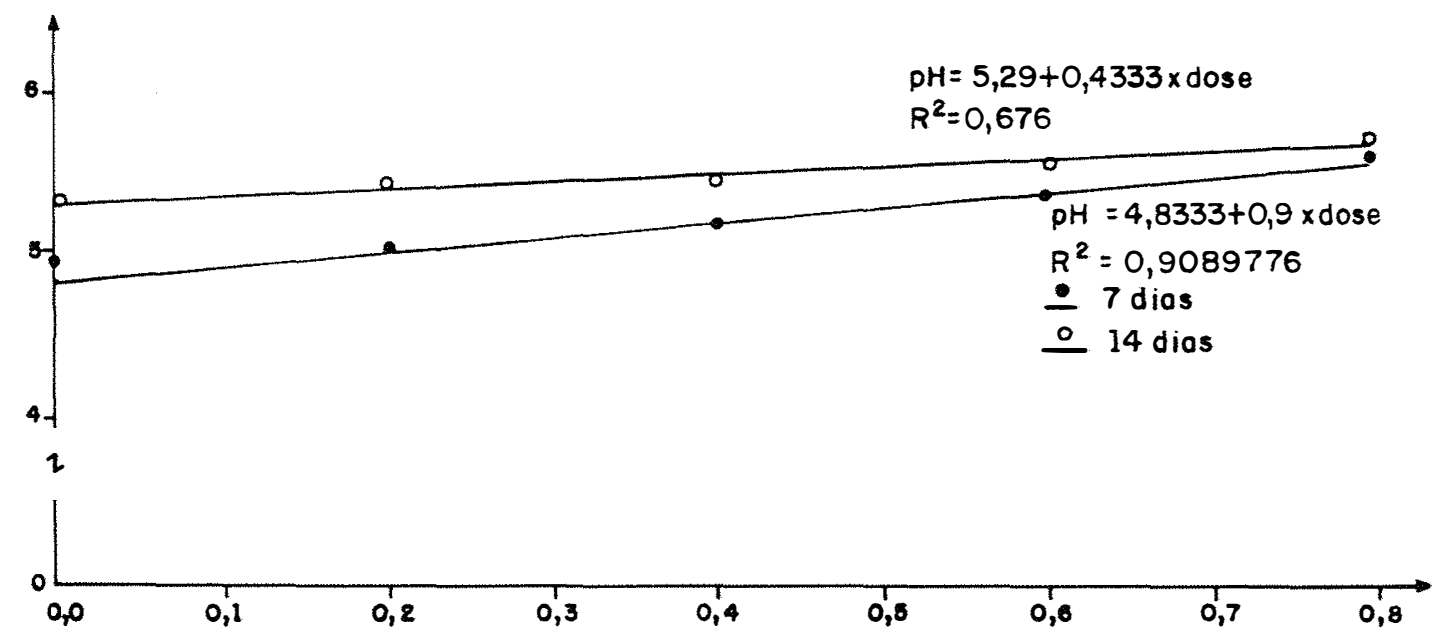

I

$\mathrm{pH}$ em $\mathrm{CaCl}_{2}$

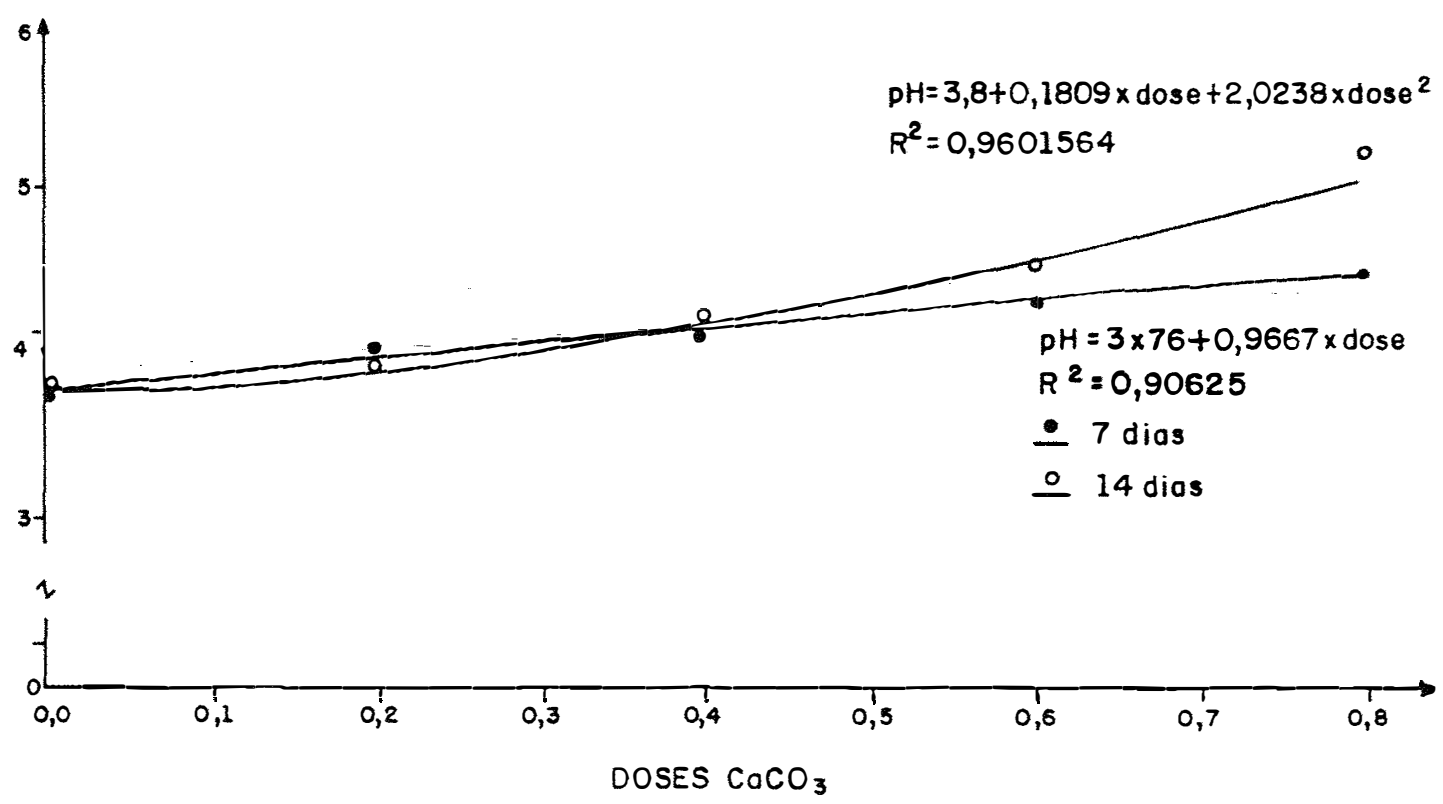

(g)

Figura 2. Variação do $\mathrm{pH}$ em água e $\mathrm{CaCl}_{2}, 0,01 \mathrm{M}$ de amostras de horizonte $\mathrm{B}$ do solo Podzólico Vermelho-Amarelo do Estado do Acre, após 7 e 14 dias de adição de diferentes doses de $\mathrm{CaCO}_{3}$. 
Uma das possíveis causas verificadas neste estudo, para explicar a ausência de sintomas de toxicidade ao alumínio nas plantas, foi a de que a avaliação deste elemento por titulação do extrato com $\mathrm{NaOH} 0,025 \mathrm{~N}$, por não ser um método específico para o alumínio, pudesse estar superestimando os resultados devido à influência de íons $\mathrm{H}^{+}$provenientes de algumas das inúmeras fontes de prótons do solo. Os resultados obtidos revelaram, contudo (Tabela 5), que os teores de Al trocável do solo, determinados por titulação alcalimétrica, foram muito coerentes com os obtidos por leitura em espectrofotômetro de absorção atômica. Essa coerência manteve-se para todas as doses de carbonato aplicadas, ou seja, ao longo de toda a faixa de variação de $\mathrm{pH}$. 


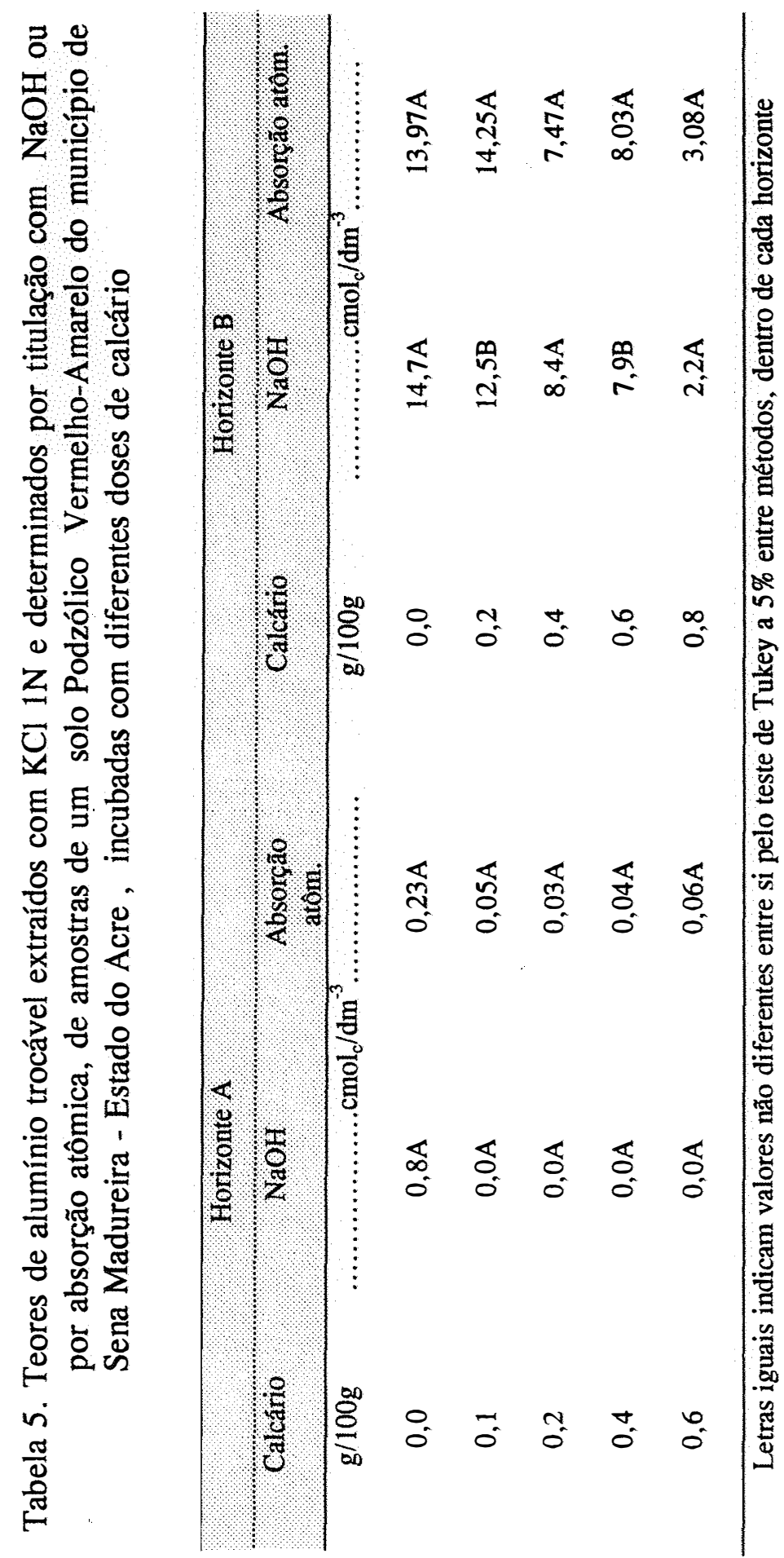




\subsection{Comportamento das espécies e/ou cultivares}

\section{plantadas em amostras de solo com elevado teor de}

\section{alumínio}

\subsubsection{Teores de alumínio, nitrogênio, fósforo e potássio nas raízes das plantas}

Os valores de $\mathrm{F}$ e respectivos graus de significância para os efeitos dos fatores estudados sobre a produção de material seco e teores de $\mathrm{Al}$, $\mathrm{N}$, P e K nas raízes das plantas encontram-se na Tabelas 6 e 7. Os teores de $\mathrm{Al}$ nas raízes das plantas tenderam a ser maiores naquelas cultivadas nas amostras do horizonte $\mathrm{B}$ que nas plantadas no A (Figura 3). Contudo, à exceção do feijão em amostras sem carbonatos, as diferenças encontradas nas raízes foram pequenas e não refltem a elevada relação de 1:73 existente entre os teores de $\mathrm{Al}$ trocável dos hotizontes $\mathrm{A}\left(0,8 \mathrm{cmol}_{\mathrm{c}} / \mathrm{dm}^{-3}\right)$ e $\mathrm{B}(14,5$ $\left.\mathrm{cmol}_{\mathrm{c}} / \mathrm{dm}^{-3}\right)$.

Mesmo com a acentuada redução do alumínio trocável no solo, com a aplicação dos carbonatos, o teor de $\mathrm{Al}$ nas raízes não foi alterado significativamente, exceto nas raízes das plantas cultivadas nas amostras do horizonte B e nem a produção de material seco aumentou salvo para as plantas de milho cultivadas nas amostras do horizonte B. 


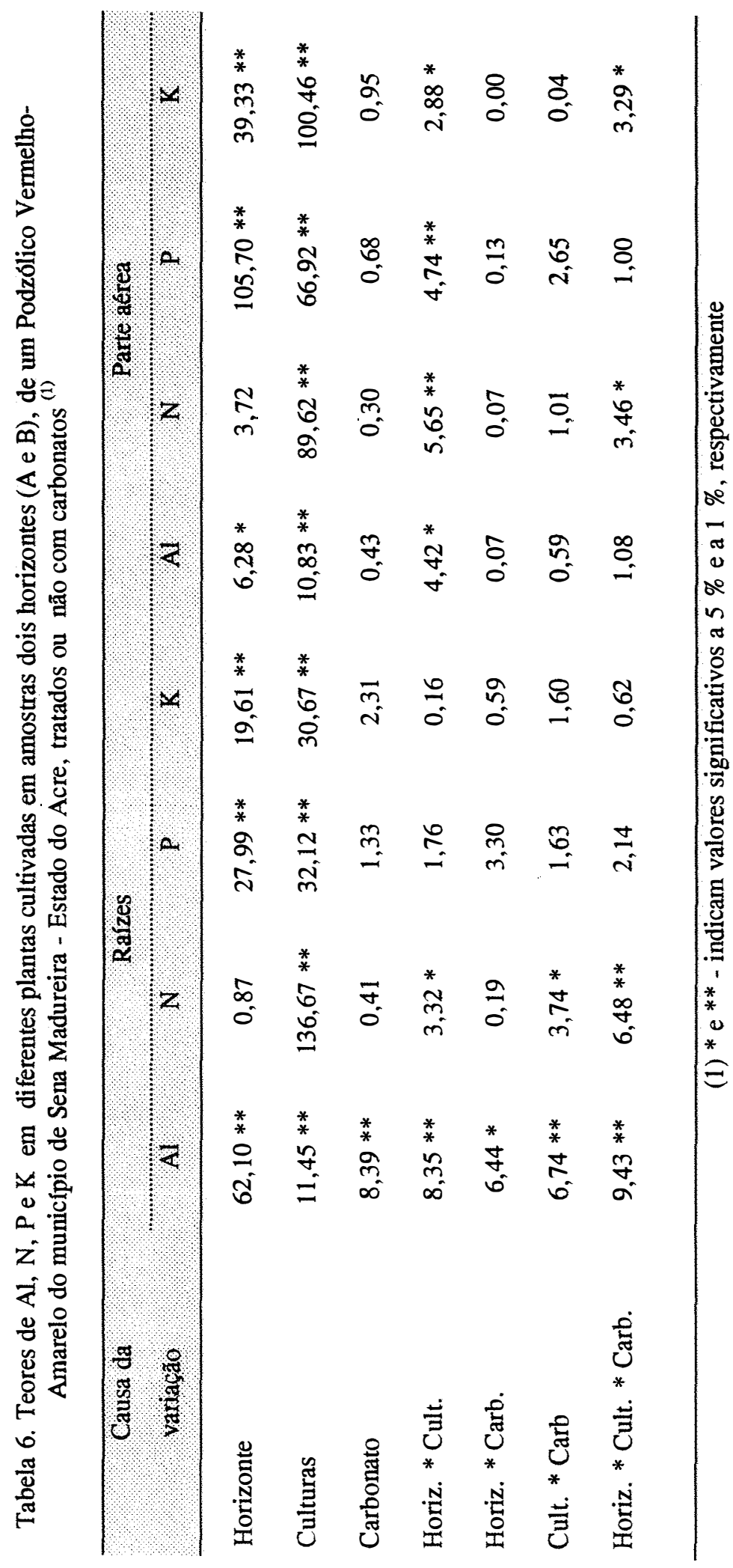




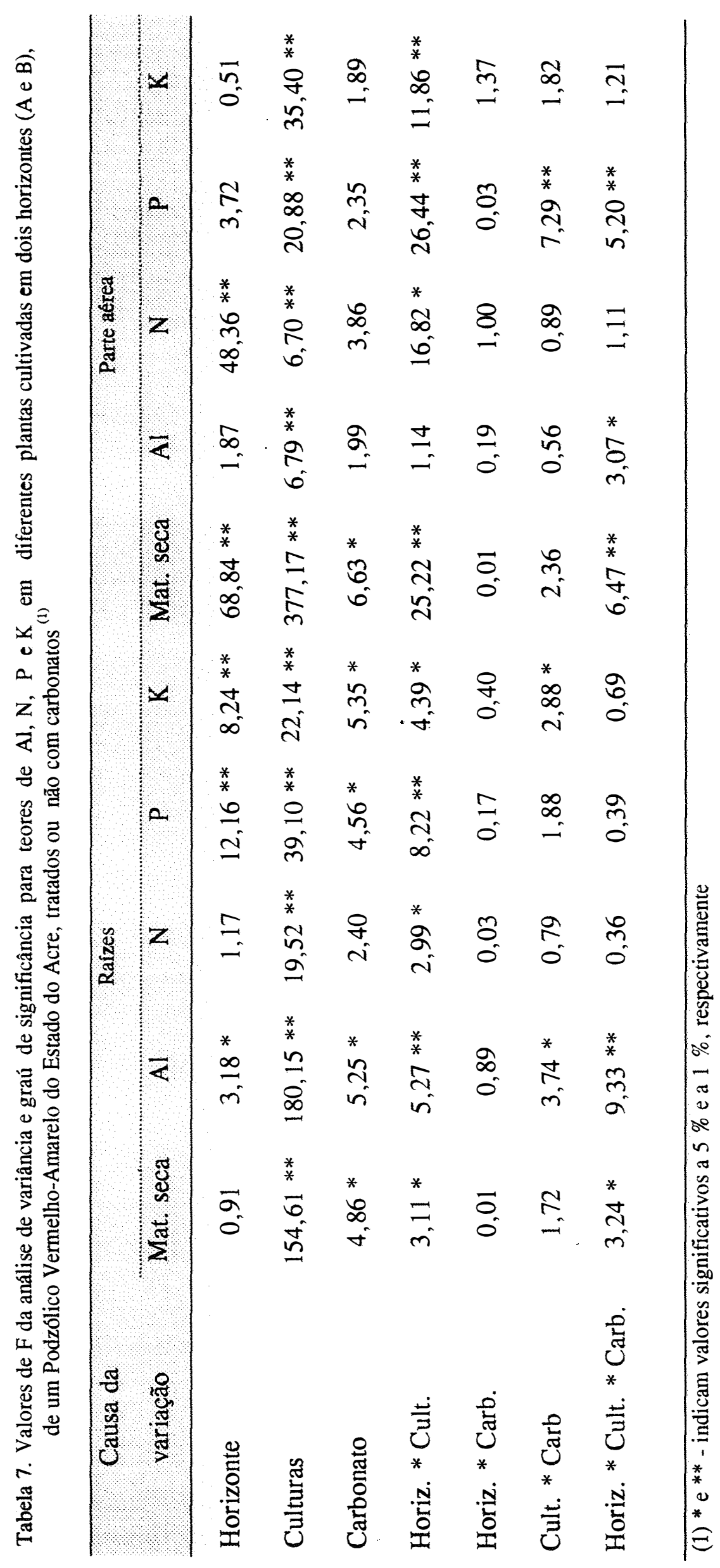


As concentrações de alumínio trocável encontradas neste trabalho contrariam os índices básicos postulados por MALAVOLTA (1980), JACKSON (1967), FOY (1974a) e outros autores. Apesar desses solos conterem elevados teores de alumínio trocável (Tabela 2), prejudicial, portanto, para as plantas, quando na solução do solo as culturas não refletiram qualquer sintoma característico oriundo da toxicidade ao alumínio. O desenvolvimento vegetativo das culturas foi excelente (Figuras 4,5 e 6 ) e o sistema radicular não apresentam quaisquer anomalias típicas de excesso de $\mathrm{Al}$, tais como crescimento reduzido, ápice espesso, ausência de raizes finas e coloração marrom (Figuras 7, 8 e 9).

CAMARGO et al. (1965), trabalhando em um solo com pH em água de 4,8 , não obtiveram resultados significativos na produção em função das doses de calcário aplicadas $(0 ; 2 ; 4$ e 6 t/ha). Do mesmo modo, POMBO \& 
HORIZONTE A

RAIZ

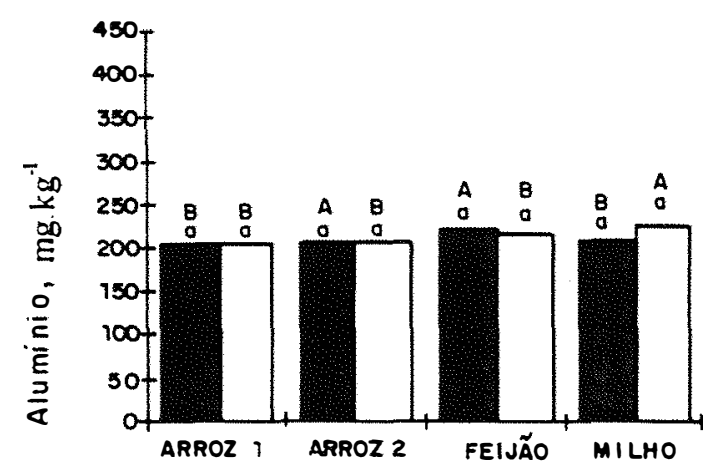

HORIZONTE B

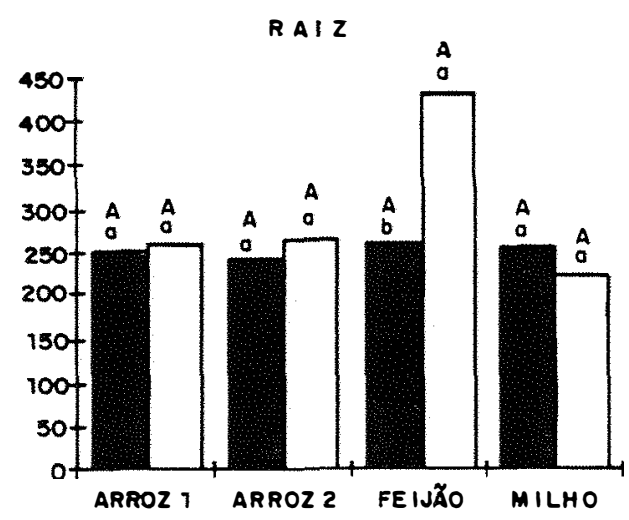

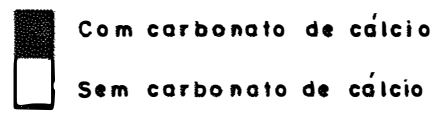

Figura 3. Teores de alumínio em diferentes plantas cultivadas em amostras de dois horizontes de um Podzólico Vermelho-Amarelo do Estado do Acre, tratadas ou não com carbonatos ( letras iguais indicam valores não diferentes entre si ao nível de $5 \%$, maiúsculas entre horizontes e minúsculas entre doses de carbonatos). 


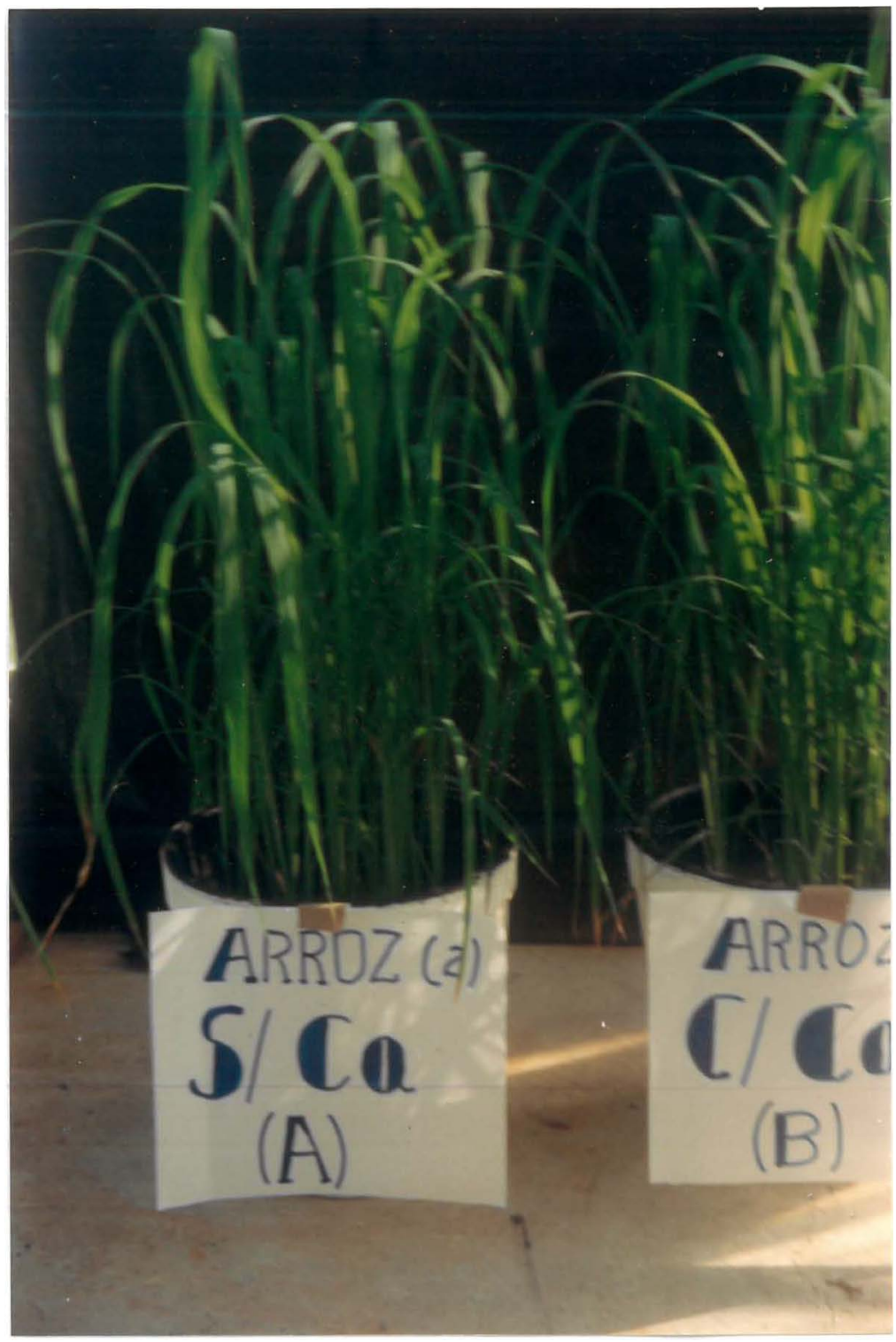

Figura 4. Desenvolvimento vegetativo da cultura do arroz em amostras terra dos horizontes A e B, de um podzólico vermalho-amarelo localizado no município de Sena Madureira,Estado do Acre, sem ou com aplicação de carbonatos. 


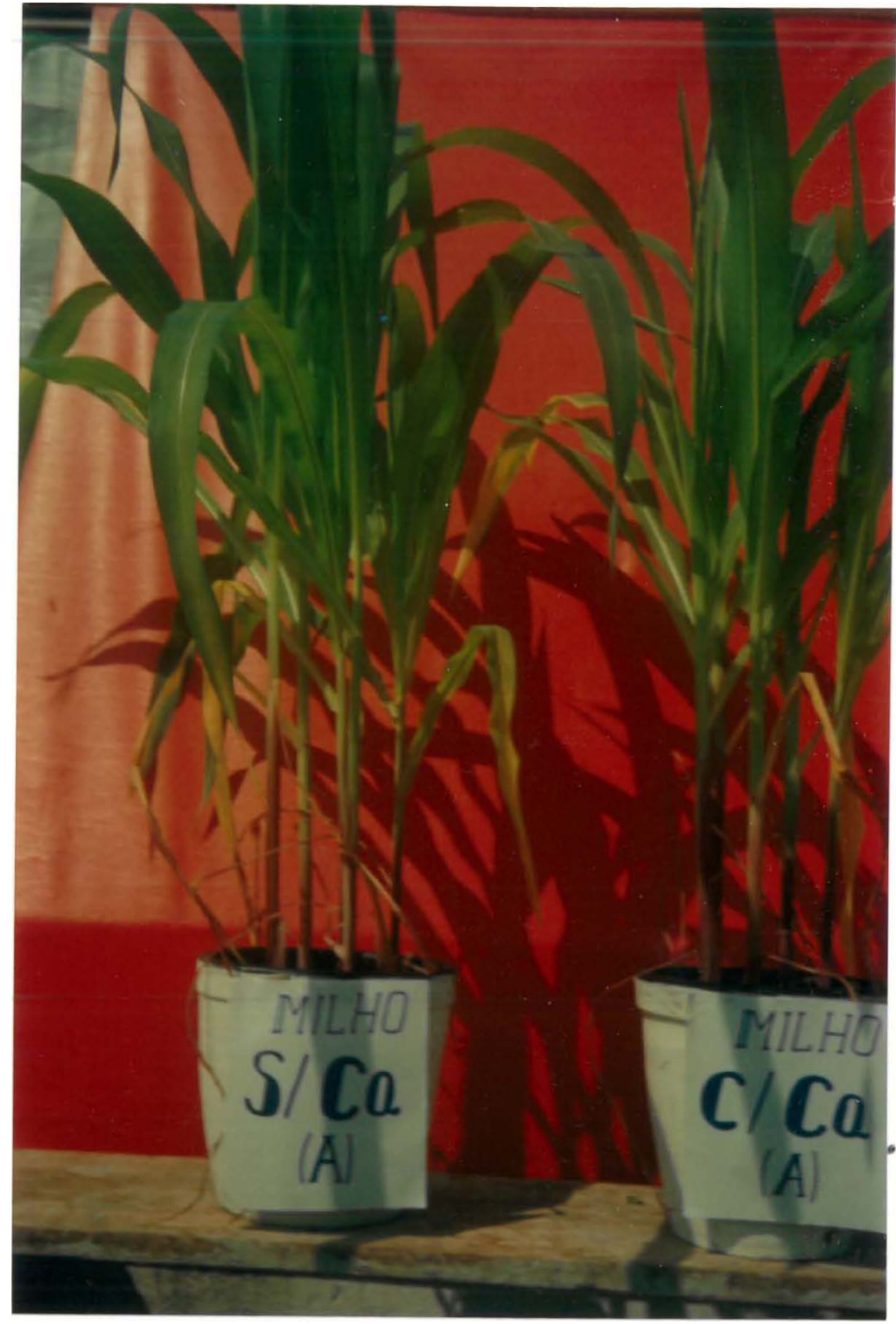

Figura 5. Detalhes do desenvolvimento vegetativo da cultura do milho em amostras de terra do horizonte A de um podzólico vermelhoamarelo localizado no município de Sena Madureira, Estado do Acre, sem ou com aplicação de carbonatos. 


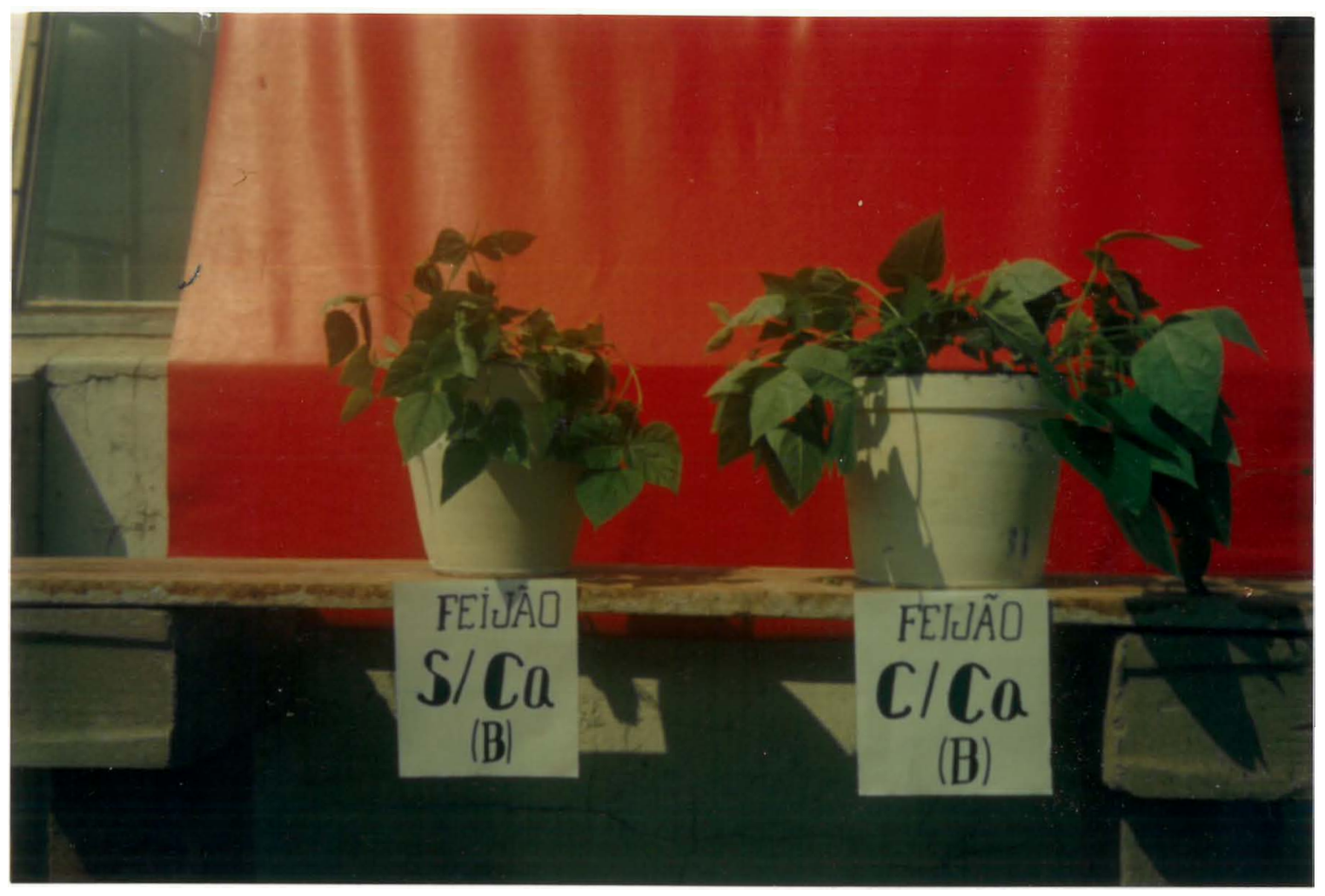

Figura 6. Plantio do feijão em amostras de terra do horizonte $B$ de um podzólico vermelho-amarelo localizado no município de Sena Madureira, Estado do Acre, sem ou com aplicação de carbonatos. 


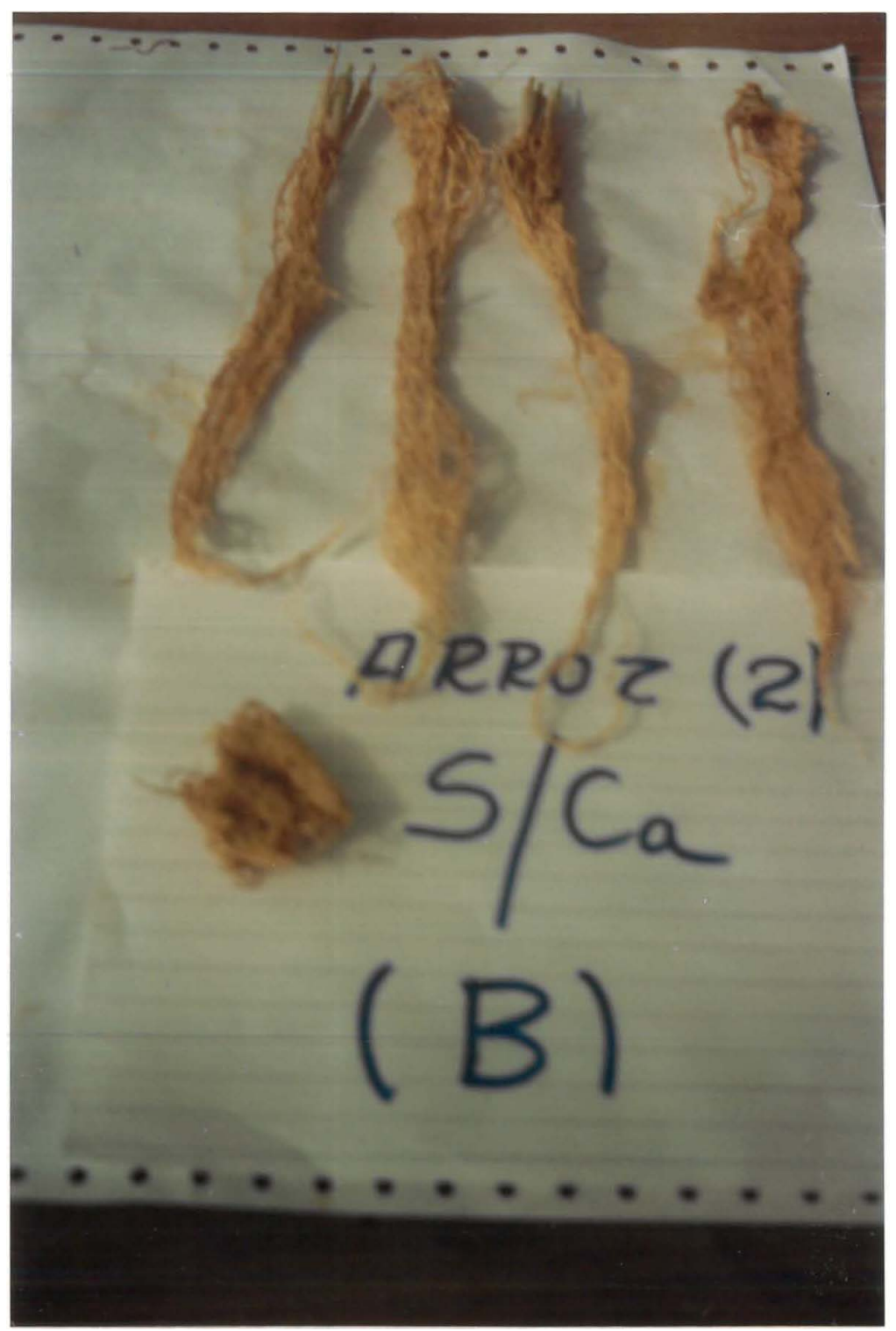

Figura 7. Sistema radicular da cultura do arroz cultivado em amostras de terra do horizonte B localizado no município de Sena Madureira, Estado do Acre, sem aplicação de carbonatos. 


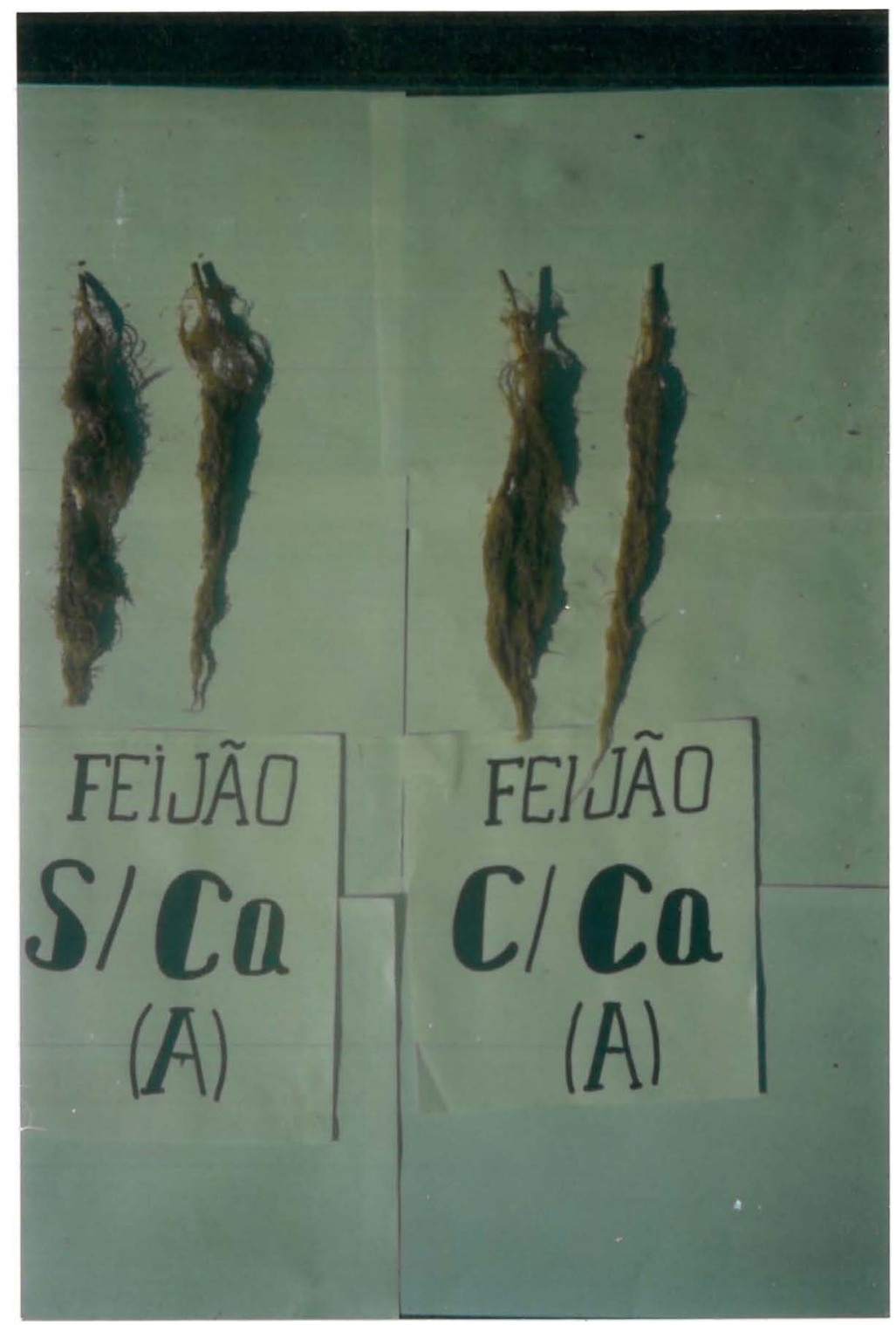

Figura 8. Raízes da cultura do feijão cultivado em amostras de terras do horizonte A de um podzólico vermalho-amarelo localizado no município de Sena Madureira, Estado do Acre, sem ou com aplicação de carbonatos. 


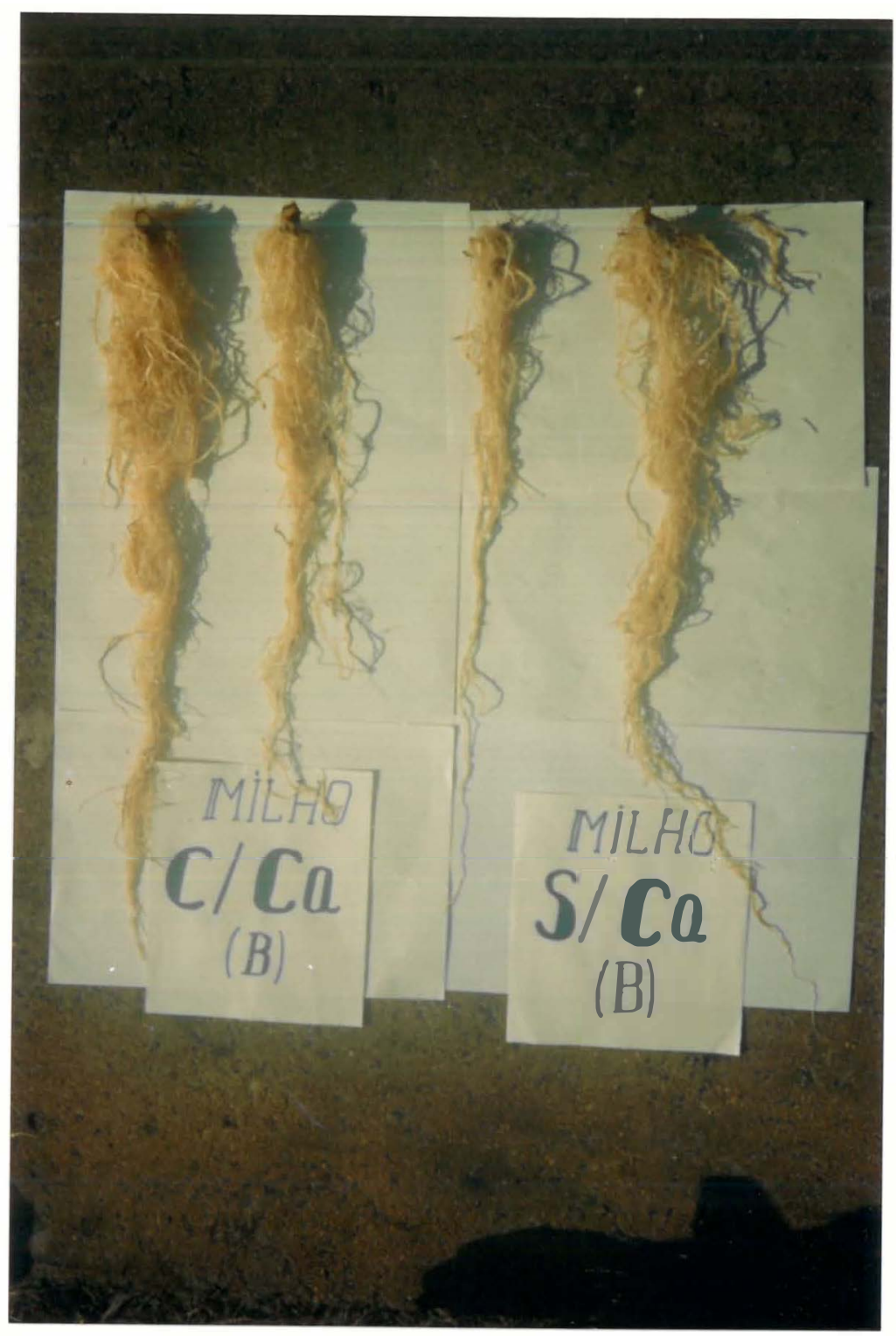

Figura 9. Detalhes do sistema radicular do milho em amostras de terras do horizonte $\mathrm{B}$ de um podzólico vermalho-amarelo localizado no município de Sena Madureira, Estado do Acre, sem ou com aplicação de carbonatos. 
SMITH (1986), estudando a influência dos calcários calcítico e dolomítico na cultura do tomateiro não obtiveram aumentos de produção.

De acordo com ADAMS \& LUND (1966), o fato de um solo possuir menor concentração de alumínio na camada superficial e uma maior toxicidade do que outro solo com concentração mais alta, traduz a influência dos fatores de formação do solo, bem como do estágio de intemperização.

A análise de variância (Tabela 6) e o teste de Tukey aplicado aos teores de nitrogênio nas raízes (Figura 10) mostraram que esta característica praticamente não foi influênciada pelos fatores "horizontes" e "carbonatos", o que indica que os teores de nitrogênio nas plantas cultivadas em amostras contendo baixos teores e altos teores de $\mathrm{Al}$ trocável pouco variaram.

Com exceção da cultura do milho, as concentrações de fósforo nas raizes foram maiores nas plantas cultivadas no horizonte $\mathrm{B}$ do que no $\mathrm{A}$, mas o efeito do corretivo não foi significativo. (Figura 11).

A concentração de potássio nas raízes foi influênciada pelo fator "horizontes" somente para culturas de arroz 1 e 2 , sendo maior nas plantas cultivadas no horizonte B que no A.. Do mesmo modo que para o fósforo, não houve efeito significativo de aplicação de carbonatos (Figura 12).

De modo geral, o alumínio foi o parametro que sofreu influência mais marcante dos tratamentos. Nas raizes das plantas as maiores concentrações de alumínio e nitrogênio ocorreram na cultura do feijão, quando cultivadas nas terras do horizonte B. O mesmo comportamento foi verificado nas culturas de 
HORIZONTE A
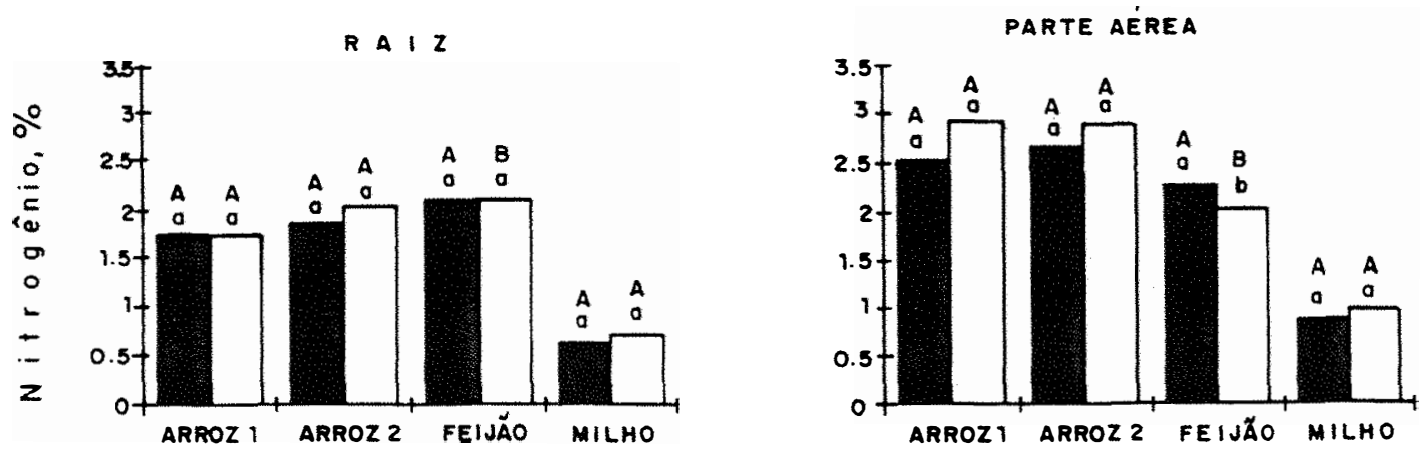

HORIZONTE B
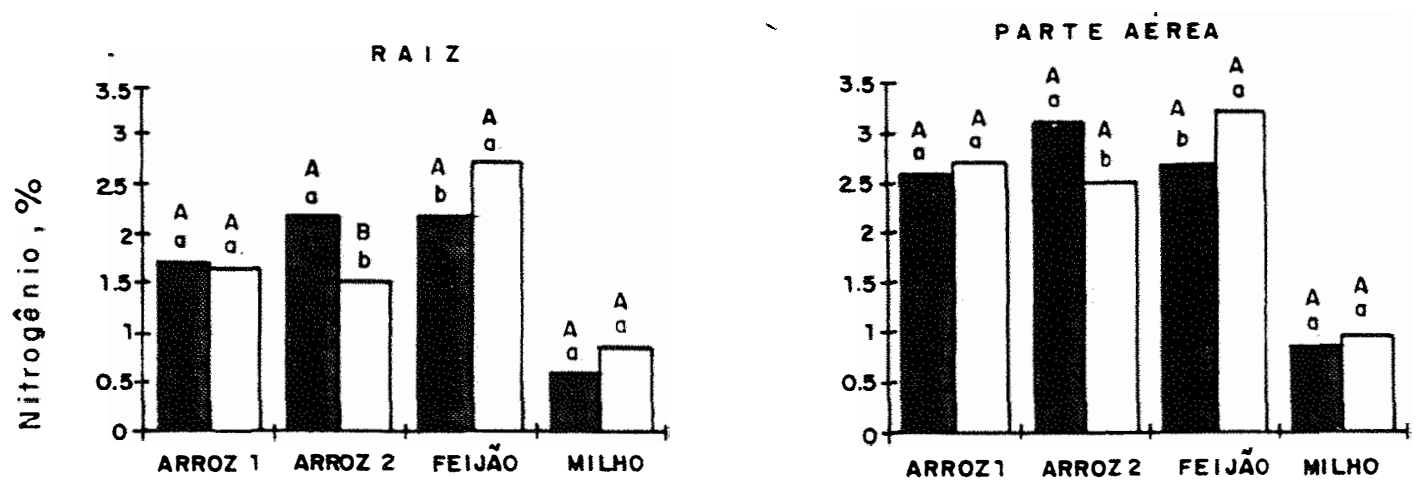

Com carbonoto de cálcio
sem corbonato de calcio

Figura 10. Teores de nitrogênio nas plantas cultivadas em amostras de dois horizontes de um Podzólico Vermelho-Amarelo do Estado do Acre, tratados ou não com carbonatos ( letras iguais indicam valores não diferentes entre si ao nível de $5 \%$, maiúsculas entre horizontes e minúsculas entre doses de carbonatos). 
RA I Z

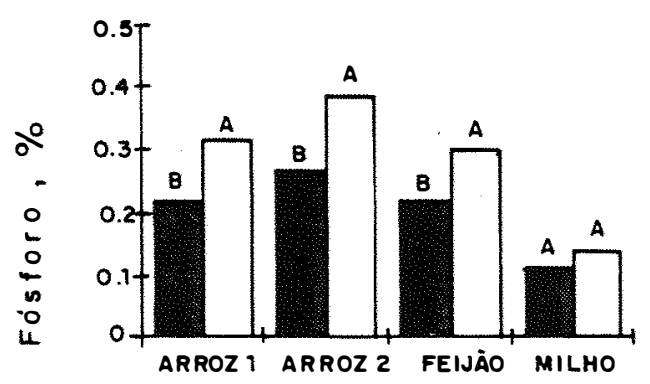

PARTE AÉREA

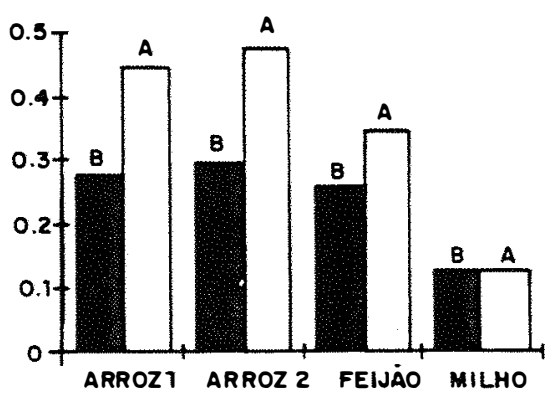

Horizonie A

Horizonie

Figura 11. Teores de fósforo nas plantas cultivadas em amostras de dois horizontes de um Podzólico Vermelho-Amarelo do Estado do Acre, tratados ou não com carbonatos ( letras iguais indicam valores não diferentes entre si ao nível de $5 \%$ ). 


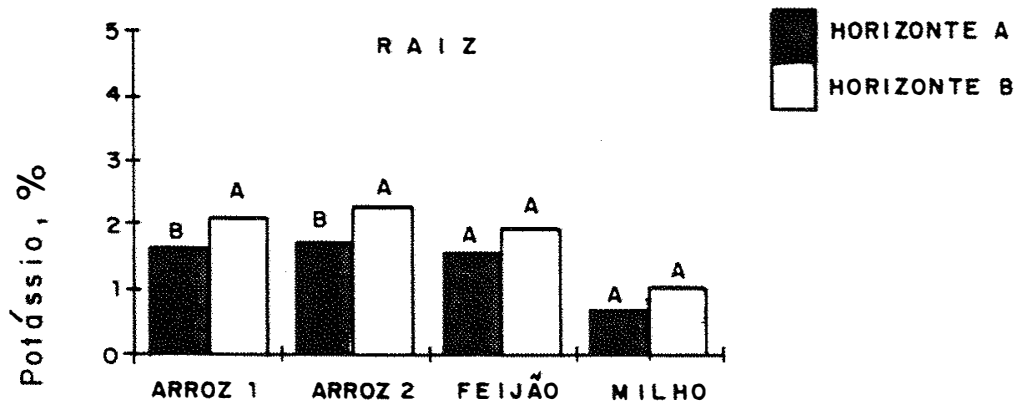

Figura 12. Teores de potássio nas plantas cultivadas em amostras de dois horizontes de um Podzólico Vermelho-Amarelo do Estado do Acre, tratados ou não com carbonatos ( letras iguais indicam valores não diferentes entre si ao nível de $5 \%$ ). 
arroz, com respeito ao fósforo e ao potássio, independentemente da aplicação de carbonatos.

\subsubsection{Teores de alumínio, nitrogênio, fósforo e potássio na parte aérea das plantas}

A Tabela 6 mostra que o teor de alumínio na parte aérea das plantas foi influenciado significativamente ao nível de 5\% pelo fator horizontes, não havendo efeito dos carbonatos. A influencia dos horizontes é explicada pela grande diferença entre os teores de alumínio trocável dos horizontes A e B.

GOMES \& CAMPOS (1990), estudando sistemas de cultivo com leguminosas e seus efeitos sobre a produtividade das culturas e as propriedades de solos podzólicos do Estado do Acre, não obtiveram resultados satisfatórios quanto aos efeitos do calcário sobre o desenvolvimento das culturas. Os autores confirmaram, através de pequena variação do $\mathrm{pH}$ em $\mathrm{KCl}$ $1 \mathrm{~N}$ encontrado antes e após sete meses da aplicação do calcário, o alto poder tampão que existe naquela área. Segundo esses autores, o método do alumínio trocável é ineficiente para determinar a quantidade de calcário a ser aplicado nesses solos, sendo mais recomendável calculá-la pela correlação existente entre o pH e a porcentagem de saturação por bases. 
O teor de nitrogênio na parte aérea das plantas não foi influenciado significativamente nem pelo fator horizontes nem pelo fator carbonatos (Tabela 6).

Os teores de fósforo e de potássio apresentaram diferenças significativas entre os horizontes, havendo maior concentração desses nutrientes nas plantas cultivadas no horizonte $\mathrm{B}$, que contém mais alumínio trocável, do que no horizonte A (Figuras 11 e 13 ). Apesar da forte influencia do carbonato em reduzir o teor de alumínio trocável do solo, o efeito do corretivo, sobre os teores de fósforo e potássio na parte aérea, não foi significativo (Tabela 6). Segundo FOY (1974a), em geral, o alumínio interfere na absorção, transporte e uso de vários nutrientes, dentre eles o fósforo. Também para OLIVEIRA (1979) o efeito mais marcante do alumínio parece ser sobre o metabolismo do fósforo, principalmente, por sua saturação ao nível radicular e redução da translocação para a parte aérea.

A tolerância de certas espécies e cultivares ao alumínio tem sido correlacionada com a habilidade das plantas em absorver e utilizar o fósforo. FOY et al.(1965a), analisando o teor de fósforo presente na parte aérea de planta de trigo tratadas com $\mathrm{Al}$, verificaram que a cultivar sensível acumulou menos fósforo na parte aérea do que a cultivar tolerante.

Nas cultivares de arroz verificou-se as maiores concentrações de fósforo e potássio, ao mesmo tempo em que a cultura do feijão evidenciou maiores concentrações de alumínio e nitrogênio. Convém observar, que o 
HORIZONTE A

PARTE AÉREA

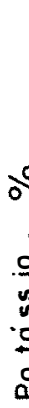

웅
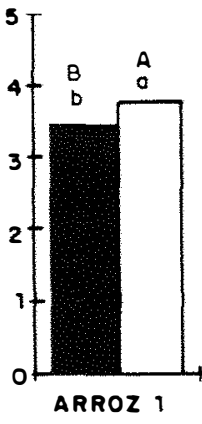
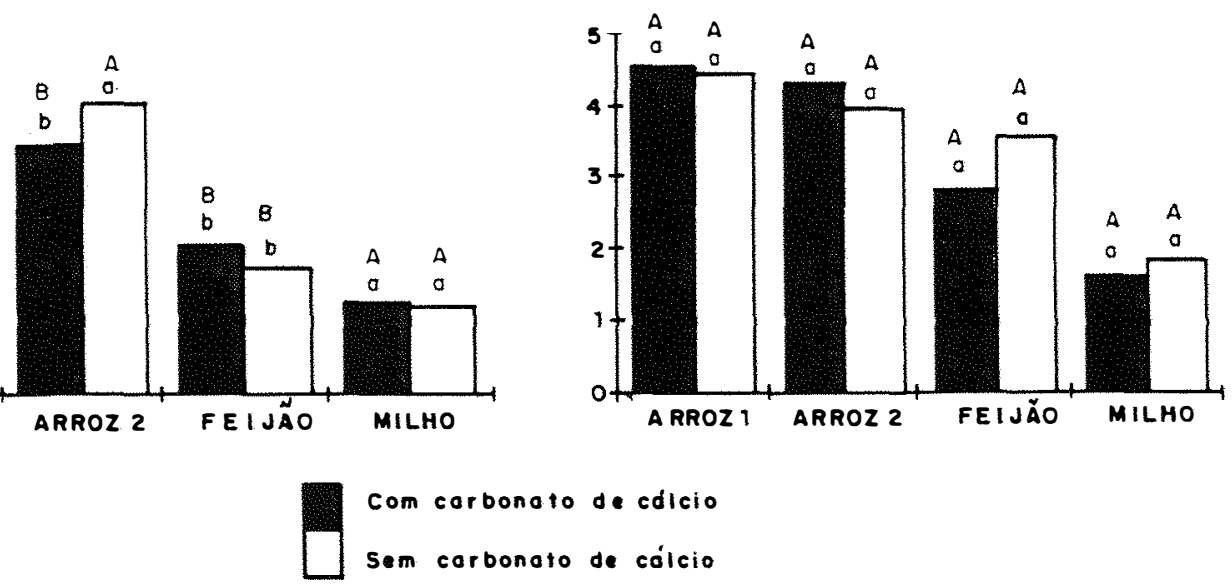

Com carbonato de cdicio

Sem carbonato de cólcio

Figura 13. Teores de potássio nas plantas cultivadas em amostras de dois horizontes de um Podzólico Vermelho-Amarelo do Estado do Acre, tratados ou não com carbonatos ( letras iguais indicam valores não diferentes entre si ao nível de $5 \%$, maiúsculas entre horizontes e minúsculas entre doses de carbonatos). 
tratamento com carbonato de cálcio não proporcionou nenhuma alteração nas interações entre as plantas e horizontes.

\subsubsection{Produção de material seco e quantidades de alumínio, nitrogênio, fósforo e potássio acumuladas nas plantas}

Os valores de $F$ e seus respectivos graus de significância obtidos pela análise de variância aplicada aos resultados de produção de material seco e as quantidades de alumínio, nitrogênio, fósforo e potássio acumulados nas plantas encontram-se na Tabela 7.

As quantidades de material seco produzidas pelas plantas encontram-se na Tabela 8, e as de Al, N, P e K acumuladas são apresentadas na Tabela 9.

A produção de material seco pelas raizes foi influenciada pelo fator horizontes somente em dois casos: na cultura do milho sem carbonato a quantidade de raízes foi maior no horizonte $\mathrm{A}$ do que no $\mathrm{B}$, contudo, as plantas de arroz 2 sem carbonatos apresentaram mais raizes no horizonte B, com alto teor de $\mathrm{Al}$ trocável, do que no horizonte $\mathrm{A}$ (Tabela 8). O efeito dos carbonatos foi significativo somente para o milho no horizonte $B$, cuja produção de raízes foi maior com a adição do corretivo do que sem sua aplicação. 


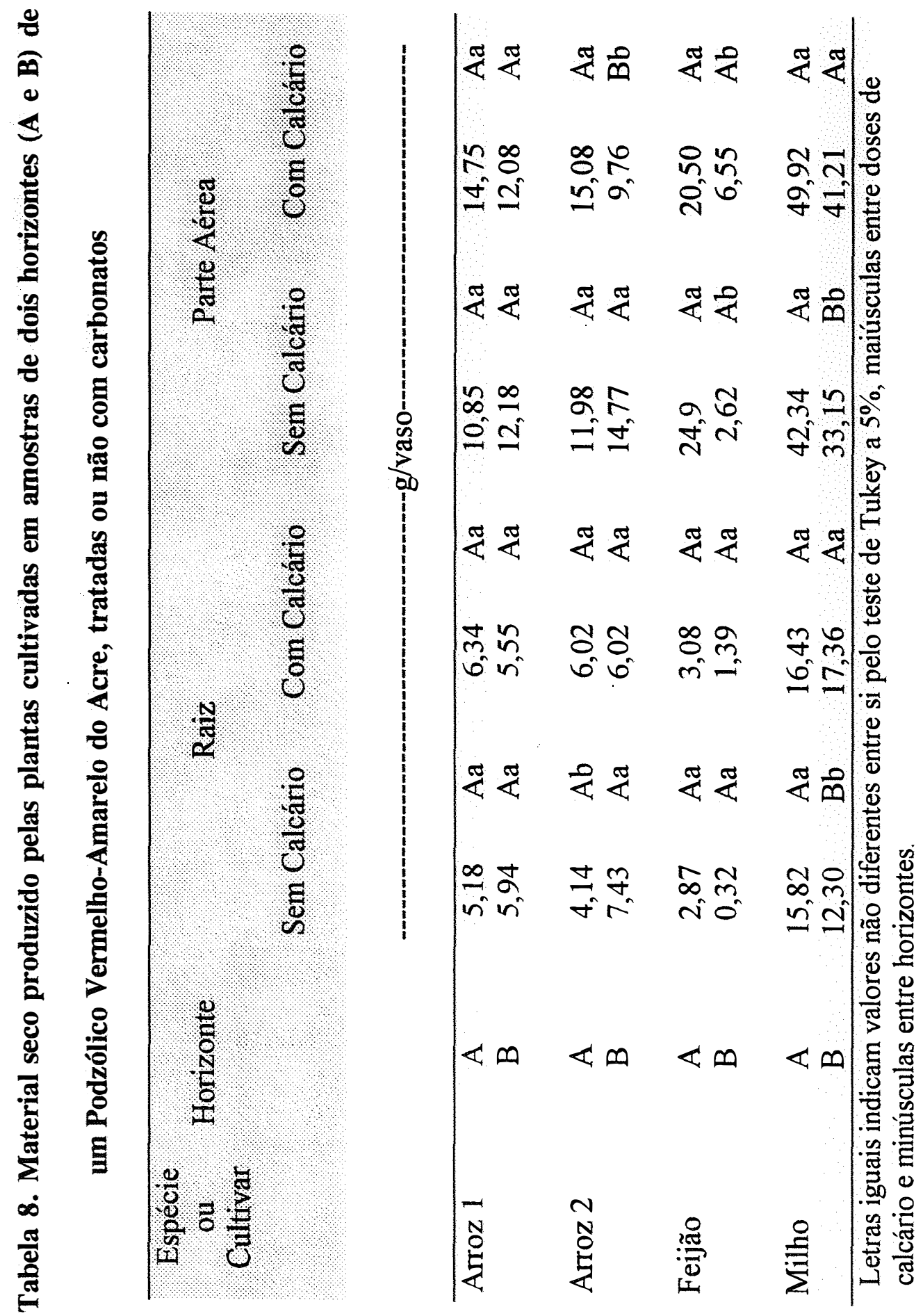




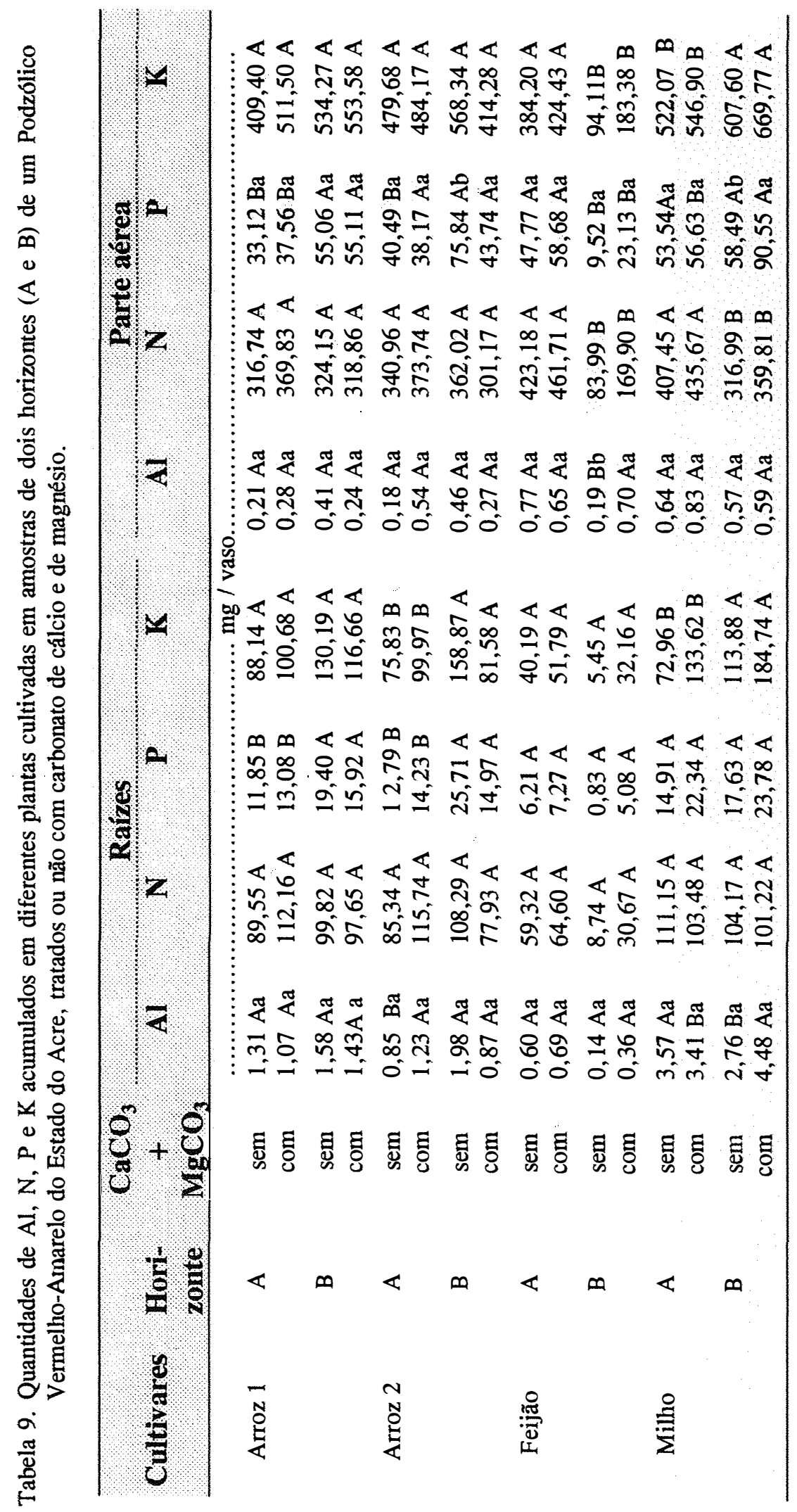


Na parte aérea, a produção de material seco foi influenciada pelo fator horizontes para todas as culturas, exceto arroz 1, havendo maior quantidade de massa seca nas plantas cultivadas no horizonte $A$ do que no B (Tabela 8). O efeito dos carbonatos foi significativo somente para o milho e para o arroz 2 cultivados no horizonte $B$, sendo que nesta última cultura a produção de material seco foi maior quando não se aplicou o carbonato.

FAGERIA et al. (1988) e FAGERIA \& ZIMMERMANN (1979), em estudos de seleção de cultivares de arroz para tolerância à toxidez de alumínio, empregando soluções nutritivas contendo $0,10,20,40$ e 60 ppm de alumínio na forma de $\mathrm{AlCl}_{3}$, encontraram diferenças entre as cultivares com relação ao peso de material seco, somente em concentrações de 40 e 60 ppm; classificando as cultivares "Femandes" e "IAC 1131" foram classificadas como de tolerância alta e baixa, respectivamente, após 21 dias de crescimento. Os resultados encontrados neste trabalho com relação ao peso de material seco e comprimentos de raízes dessas cultivares são maiores do que as pesquisas efetuadas pelos autores quando comparadas com às quantidades de alumínio trocável citados na Tabela 2.

A quantidade de $\mathrm{Al}$ acumulada nas raizes das plantas não foi influenciada pela aplicação do corretivo exceto em dois casos : nas raízes do milho e na parte aérea do feijão no horizonte $B$, nos quais as quantidades encontradas com aplicação do calcário foram, incoerentemente, maiores do que as obtidas sem a aplicação (Figura 14). 
HOR I Z O N T E A
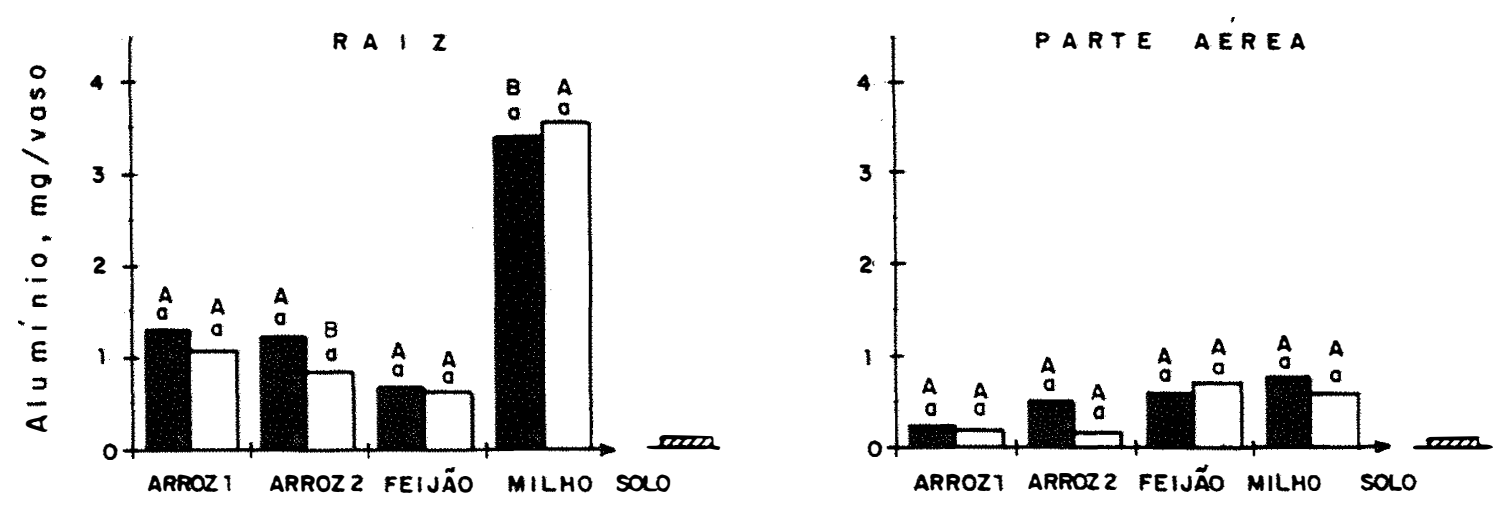

HORIZONTE B

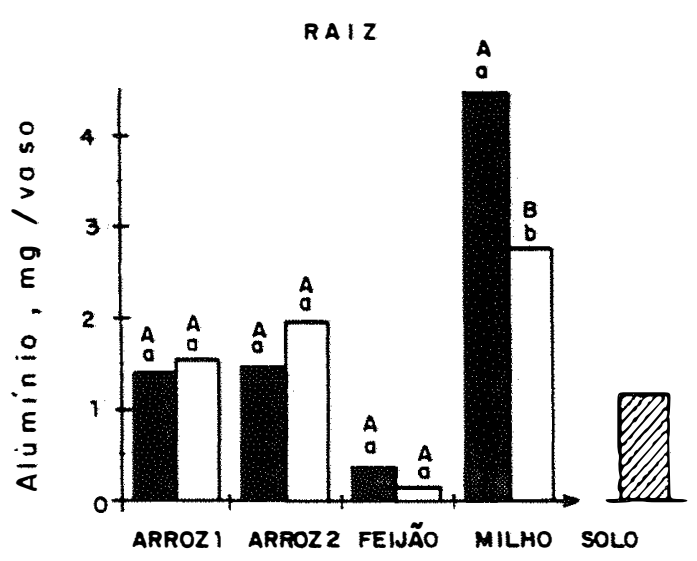

PARTE AÉREA
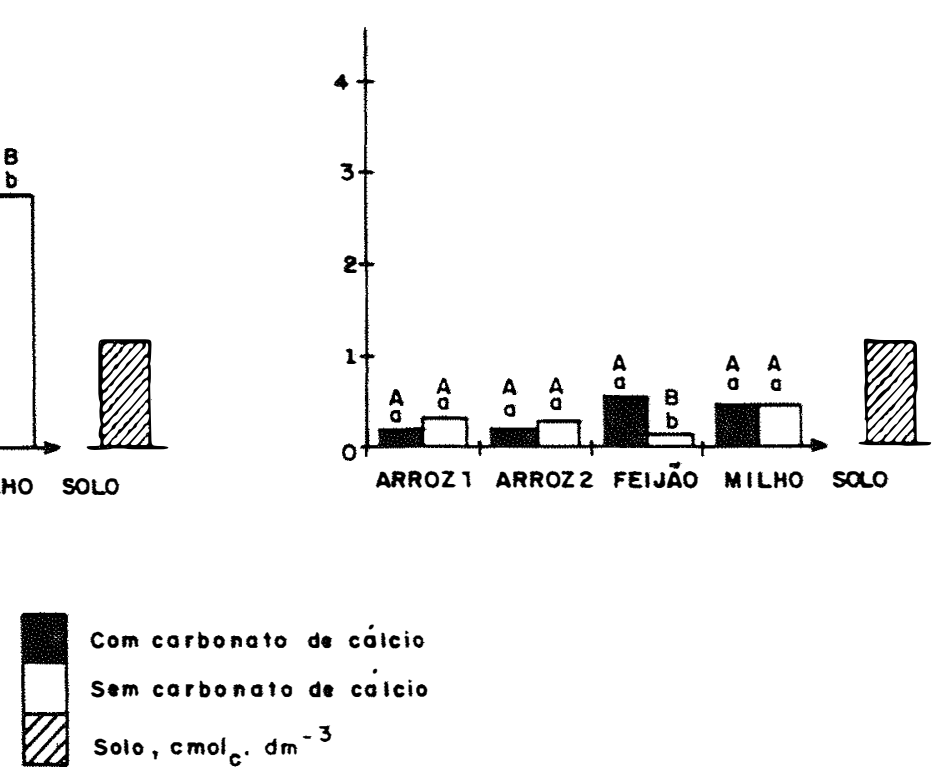

Figura 14. Quantidade de alumínio acumulado em plantas cultivadas em amostras de dois horizontes de um Podzólico Vermelho-Amarelo do Estado do Acre, tratados ou não com carbonatos ( letras iguais indicam valores não diferentes entre si ao nível de $5 \%$, maiúsculas entre horizontes e minúsculas entre doses de carbonatos). 
As quantidades acumuladas nas raízes de $\mathrm{Al}$ foram influenciadas pelo fator horizontes somente em dois casos: arroz 2 sem aplicação de carbonato e milho com aplicação de carbonato. Em ambos, as quantidades acumuladas foram maiores nas plantas cultivadas no horizonte $\mathrm{B}$ ue no horizonte A. Na parte aérea o único efeito significativo ocorreu para o feijão sem aplicação de carbonatos, em cuja cultura a quantidade acumulada foi inexplicavelmente maior no horizonte A do que no B (Figura 14).

Os resultados referentes ao desenvolvimento das culturas e ao crescimento do sistema radicular parecem não obedecer, nestes solos, os conceitos postulados e descritos por CLARKSON (1965) e FOY (1978) sobre os sistemas de toxicidade e os mecanismos de tolerância interna dos vegetais ao alumínio acumulado, também defendidos por FURLANI (1989).

Apesar do solo apresentar uma quantidade elevada de alumínio trocável nos seus horizontes (Tabela 2), o desenvolvimento vegetativo das culturas mostrou que estas não apresentaram qualquer sintoma de toxicidade ao alumínio, mesmo nos tratamentos que não receberam corretivos (Figuras 4, 5 e 6) o que contradiz os conceitos descritos por aqueles autores. MALAVOLTA (1980) considera como prejudicial para as plantas, teores de alumínio trocável no solo acima de $0,5 \mathrm{cmol}_{\mathrm{c}} / \mathrm{kg}$ de solo. Medições do comprimento das raízes das culturas estudados, quando plantadas em amostras do horizonte $\mathrm{B}$, mostram que o sistema radicular apresentou desenvolvimento normal, e que o controle do $\mathrm{Al}$ trocável com carbonatos não estimulou esse 
estudados, quando plantadas em amostras do horizonte $B$, mostram que o sistema radicular apresentou desenvolvimento normal, e que o controle do $\mathrm{Al}$ trocável com carbonatos não estimulou esse desenvolvimento (Tabela 10), o que não condiz com os resultados dos trabalhos executados por FAGERIA \& ZIMMERMANN (1979), FOY et al. (1972, 1965a, e 1974b) e PAVAN (1982).

Tabela 10. Comprimentos mínimo e máximo de raízes de plantas cultivadas em amostras do horizonte B de um solo Podzólico VermelhoAmarelo do Estado do Acre, tratadas ou não com carbonatos.

\begin{tabular}{|c|c|c|c|c|}
\hline \multirow{2}{*}{$\begin{array}{c}\mathrm{CaCO}_{3}+ \\
\mathrm{MgCO}_{3}\end{array}$} & \multicolumn{4}{|c|}{ Culturas $^{(1)}$} \\
\hline & Arroz 1 & Arroz 2 & Feijão & Milho \\
\hline & …….................. & …................. & $\mathrm{cm} . . . \ldots \ldots$ & 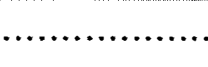 \\
\hline sem & $27-32$ & $26-27$ & $18-19$ & $55-61$ \\
\hline com & $21-30$ & $26-32$ & $19-22$ & $53-65$ \\
\hline
\end{tabular}

(I) Arroz 1, cultivar "Fernandes; Arroz 2, IAC 1131. 
O desenvolvimento do sistema radicular não apresentou inibição no crescimento pois as raízes eram longas, filiformes e de superficies externas regulares e brancas, com raizes laterais bem acima da região apical da raiz principal em todas as culturas (Figuras 7, 8 e 9).

RAGLAND \& COLEMAN (1960), estudando o efeito do cálcio e do alumínio na solução de diversos solos sobre o crescimento da raiz do milho, evidenciaram que nos solos sem calcário, quando o teor o alumínio trocável aumentava, o crescimento das raízes diminuia, mas, quando se adicionava o calcário, o crescimento das raízes aumentava. Todavia, a percentagem de aumento foi maior onde a quantidade de alumínio trocável era maior.

As quantidades acumuladas de nitrogênio nas raizes e na parte aérea não foram influenciadas significativamente pela aplicação do carbonato (Tabela 7). As culturas do feijão e milho manifestaram maior acúmulo quando plantadas nas amostras do horizonte A (Figura 15), enquanto para as demais culturas de arroz não houve efeito do fator horizonte.

Para o fósforo nas raízes, houve efeito significativo entre horizontes somente nas culturas de arroz, devido à maior quantidade acumulada no horizonte $\mathrm{B}$. Na parte aérea o efeito dos horizontes não foi significativo, somente na culturas de arroz 2 com carbonatos e na de milho sem carbonatos; nos casos em que houve significância, ora o acúmulo foi maior nas plantas cultivadas no horizonte A, ora naquelas cultivadas no horizonte B (Figura 16). PAVAN (1982) também não obteve efeito interativo 
horizonte B (Figura 16). PAVAN (1982) também não obteve efeito interativo de alumínio sobre desenvolvimento nas mudas de cafeeiro. Os resultados indicaram que a absorção do cálcio pelas plantas foi progressivamente diminuída com o aumento da concentração de aluminio na solução.

A baixa produção de material seco de feijão obtida no horizonte B (Tabela 8) pode estar relacionada com o baixo teor de matéra orgânica, ocasionando portanto, pouca contribuição no conteúdo de molibidênio

para auxiliar na fixação de nitrogênio para o feijão. Além disso, a calagem pode ter causado agravamento numa possível deficiência de alguns micronutrientes, como o zinco por exemplo.

Para as quantidades de potássio nas raizes, houve efeito significativo para horizontes nas culturas de milho e arroz 2, sendo que os teores desse nutriente foram maiores para o horizonte $\mathrm{B}$ do que para o $\mathrm{A}$, ao contrario do esperado (Figura 17). De modo contrário, a ação do carbonato sobre a quantidade de potássio na parte aérea das plantas não foi significativa. 
PARTE AÉREA

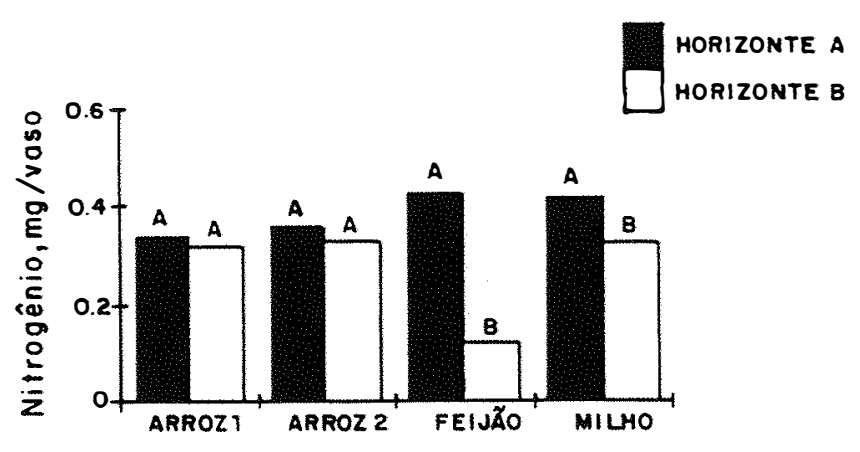

Figura 15. Quantidade de nitrogênio acumulado nas plantas cultivadas em amostras de dois horizontes de um Podzólico Vermelho-Amarelo do Estado do Acre (letras iguais indicam valores não diferentes entre si ao nível de $5 \%$ entre horizontes). 
PARTE AÉREA
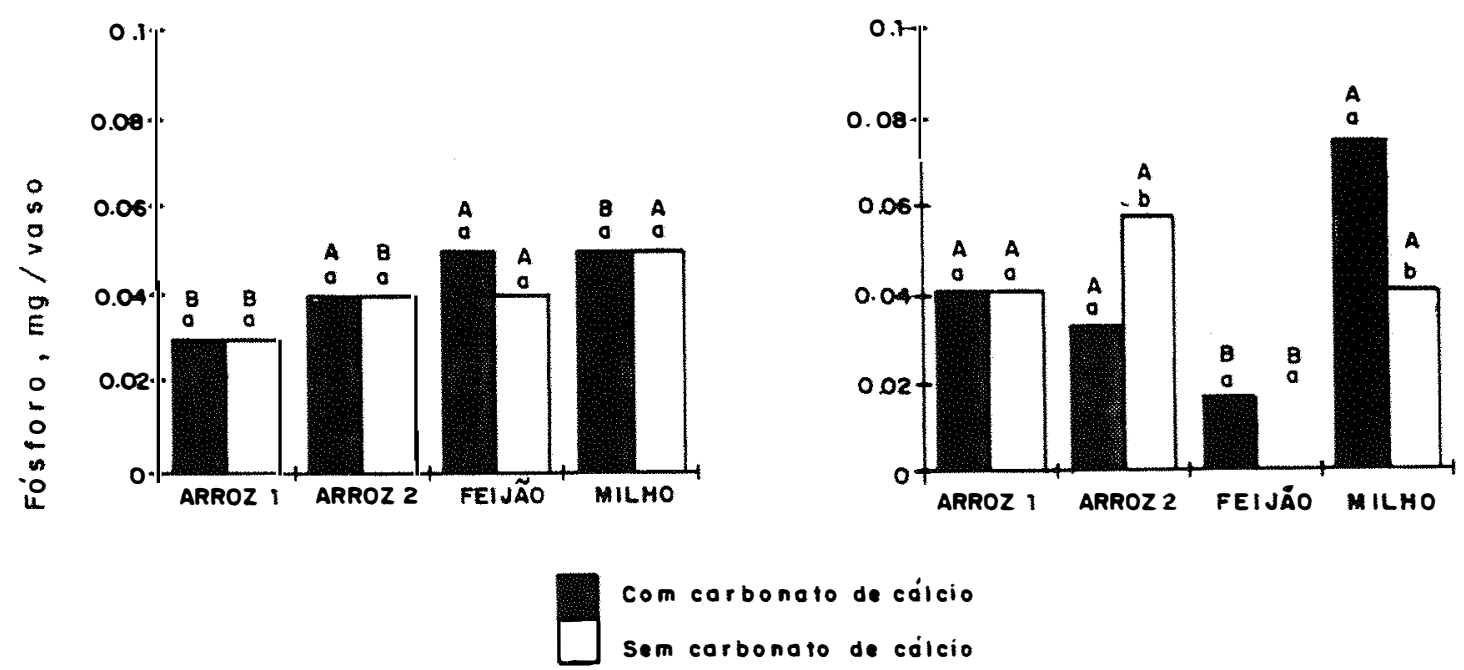

Figura 16. Quantidade de fósforo acumulado nas plantas cultivadas em amostras de dois horizontes de um Podzólico Vermelho-Amarelo do Estado do Acre, tratados ou não com carbonatos ( letras iguais indicam valores não diferentes entre si ao nível de $5 \%$, maiúsculas entre horizontes e minúsculas entre doses de carbonatos). 

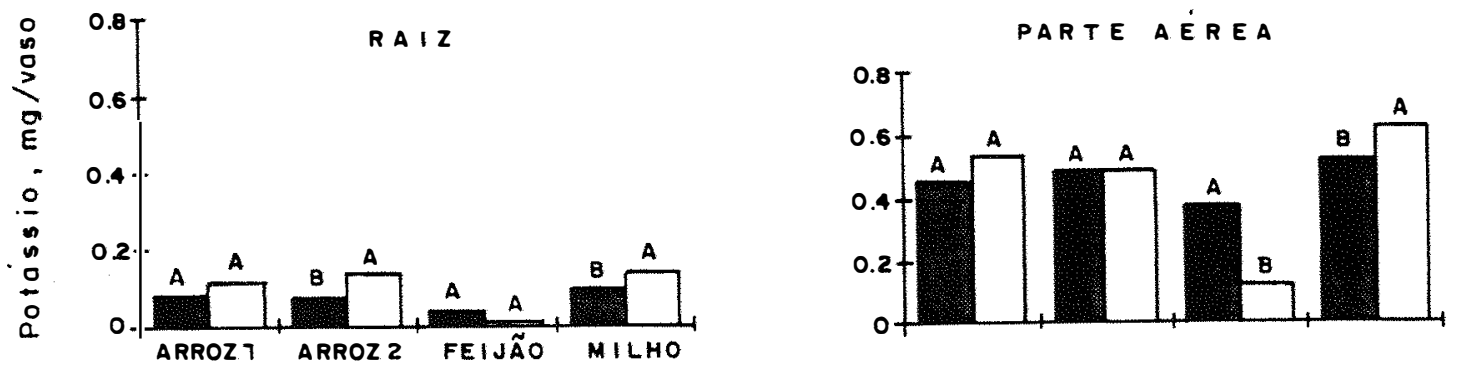

Figura 17. Quantidade de potássio acumulado nas plantas cultivadas em amostras de dois horizontes de um Podzólico Vermelho-Amarelo do Estado do Acre (letras iguais indicam valores não diferentes entre si ao nível de $5 \%$ entre horizontes). 


\subsection{Avaliação do teor de alumínio na solução do solo}

Conforme foi mostrado nos itens anteriores, embora os teores de alumínio trocável do solo Podzólico Vermelho-Amarelo estudado fossem elevados, as culturas nele desenvolvidas não apresentaram os sintomas característicos de toxicidade desse elemento nas raizes e na parte aérea. Além disso, a aplicação do corretivo também não modificou apreciavelmente a produção de material seco e nem os teores e as quantidades acumuladas de alumínio, nitrogênio, fósforo e potássio. Em algumas plantas, a produção de material seco e a absorção de nutrientes foi incoerentemente maior quando não se aplicou o corretivo do que quando este foi aplicado, particularmente nas amostras do horizonte $\mathrm{B}$.

Para pesquisar a ausência de toxicidade de alumínio sobre as plantas, um experimento adicional foi conduzido incubando-se amostras de solo com diversas quantidades de carbonato, durante 14 dias, nos moldes do experimento descrito anteriormente e, determinando-se os teores de alumínio na solução do solo de acordo com o descrito no ítem 3.4. Os resultados mostraram que o solo, apesar de conter elevados níveis de alumínio trocável, possui teores muito baixos ou mesmo nulos desse elemento na solução (Tabela 11).

Ao contrário do que foi efetuado neste trabalho, CARVALHO (1994) estudando cinco latossolos ácidos para comparar a aplicação de sulfato 
de cálcio, fosfogesso e carbonato, utilizou a metodologia descrita por RHOADES (1982) e conseguiu obter resultados equivalentes a 36,3 umol. $\mathrm{L}^{-1}$ em sua maior proporção em um pH 3,93 na solução dos solos estudados.

SMYTH \& CRAVO (1992), estudaram os problemas de deficiência de cálcio e excesso de alumínio em oxisol da amazônia para produção contínua de alimentos, utilizando calcário e gesso para as culturas de milho, sija, amendoím e caupí. Observaram que a saturação de aluminio no solo para milho e soja não deve ser superior a $27 \%$, enquanto que para o amendoím o nível crítico seria de 54\%.

Os mesmos autores observaramtambém uma estreita correlação entre a produçào das culturas e a relação $\mathrm{Ca} / \mathrm{Al}$ trocáveis no solo obtendo um valor crítico de 0,42 para obtenção máxima da produção. Isso indica que a produção das pode não ser afetada pela quantidade de alumínio trocável desde que exista uma quantidade suficiente de cálcio para manter essa relação constante.

Nos solos estudados a relação $\mathrm{Ca} / \mathrm{Al}$ trocáveis é da órdem de 14,6 para o horizonte A com baixa saturação de alumínio, e 0,48 para o horizonte B com saturação de alumínio de $59 \%$, oque é prejudicial para a maioria das culturas. Esses fatos podem explicar a ausência de toxicidade ao alumínio observado nas plantas cultivadas nas terras do podzólico vermelhoamarelo deste trabalho.

CHAVES et al. (1881), avaliaram a absorção do cálcio e alumínio pelas raizes do cafeeiro em dois latossolos ácidos, após adições de 
CHAVES et al. (1881), avaliaram a absorção do cálcio e alumínio pelas raizes do cafeeiro em dois latossolos ácidos, após adições de $\mathrm{MgCO}_{3}, \mathrm{CaCO}_{3}, \mathrm{CaCl}$ e $\mathrm{CaSO}_{4}$ e concluíram dentre outros resultados que o $\mathrm{CaCO}_{3}$ pH 6,0 aumentou o teor de $\mathrm{Ca}+$ e eliminou o $\mathrm{Al}^{3+}$ na solução do solo e que o $\mathrm{CaSO}_{4}$ diminuiu os teores de $\mathrm{Al}^{3+}$ e $\mathrm{Ca}^{2+}$ na solução do solo, em face da formação das espécies $\mathrm{AlSO}_{4}{ }^{-}$e $\mathrm{CaSO}_{4}{ }^{\circ}$. Os mesmos autores verificaram que a massa de materia seco das plantas aumentou com a elevaçãode teorres de $\mathrm{Ca}^{2+}$ e diminuição de $\mathrm{Al}^{3^{+}}$na solução do solo.

BRUCE et al. (1988), estudando o efeito do cálcio e alumínio na solução de um solo ácido no alongamento de raíz de Glycine max, verificaram que a primeira limitação no crescimento da raíz foi devida à deficiência de cálcio e não à toxicidade a o alumínio trocável, apezar da alta saturação deste elemento e relativo baixo $\mathrm{pH}$ no solo. Admitem também que a toxicidade ao alumínio pode ser induzida pelo aumento da fôrça iônica da solução do solo.

Os mesmos autores acima confirmaram também que a atividade é mais importante do que concentração e que o aluminio é tóxico em atividade baixa. Sugerem que $\mathrm{Al}(\mathrm{OH})_{2}{ }^{+}$e $\mathrm{AlSO}_{4}{ }^{+}$não são espécies tóxicas.

ALVA et al. (1986), estudaram o efeito da relação P/Al e concentração de cálcio como resposta à toxicidade ao alumínio em soja e cevada e concluíram que o alongamento das raízes cresceu quando a relação molar $\mathrm{P} / \mathrm{Al}$ e concentração de cálcio foi aumentada. Este aumento foi relacionadoà redução do $\mathrm{Al}$ na solução. Apezar dos baixos teores de $\mathrm{P}$ no solo 
estudado, admite-se a possibilidade do acréscimo de P pela adubação no solo, possa interferir do mesmo modo que os estudos dos autôres acima.

PAVAM et al. (1982), realizando um experimento em vasos com amostras de seis solos ácidos do Paraná (Ultisols e Oxisols), demonstraram que a redução no crescimento das raízes do cafeeiro foi melhor correlacionada com a atividade molar do $\mathrm{Al}^{3+}$ na solução do que com o teor da forma trocável. Os mesmos autores demonstraram, também, que os níveis críticos para $0 \mathrm{Al}^{3+}$ trocável, para a porcentagem de saturação por alumínio e para as concentrações de $\mathrm{Al}$ total e $\mathrm{Al}^{3+}$ na solução foram diferentes em cada solo estudado. No caso do alumínio trocável, os níveis críticos foram 0,70 , $1,30,0,30,1,00,0,19$ e $1,09 \mathrm{cmol}_{\mathrm{c} .} \mathrm{dm}^{-3}$, enquanto que para a atividade do $\mathrm{Al}^{3+}$ na solução foi de aproximadamente $4 \times 10^{-4} \mathrm{cmol} \mathrm{L}^{-1}$ para todos os solos estudados. Esses resultados confirmam os dados obtidos por ADAMS \& LUND (1966) e, sugerem que os níveis críticos de Al tóxico na solução, são diferentes para cada solo e espécie de planta.

FURLANI \& BERTON (1992) têm demonstrado a dificuldade em se definir uma concentração crítica de Al. Os fatores do meio de crescimento das plantas (solução nutritiva ou solo), tais como: $\mathrm{pH}$, fôrça iônica da solução, espécie vegetal, presença de quelatos ligantes e outros, podem atuar na modificação da resposta da planta ao alumínio. Segundo ADAMS (1984), não é o $\mathrm{Al}^{3+}$ trocável que é tóxico para as plantas, e sim o alumínio na solução. 
CARVALHO (1994), estudando técnicas de melhoria do ambiente radicular, de cinco subsolos ácidos de São Paulo com baixos teores de cálcio $\left(<3,0 \mathrm{mmol}_{\mathrm{c}} \cdot \mathrm{dm}^{-3}\right)$ e alumínio trocável de até $13,8 \mathrm{mmol}_{\mathrm{c}} \cdot \mathrm{dm}^{-3}$ ,evidenciou que os solos apresentaram severas restrições no desenvolvimento radicular das plantas de milho, devido à deficiência de cálcio e/ou toxicidade ao alumínio.

PAVAM \& BINGHAM (1982), cultivando cafeeiros em solução nutritiva, encontraram limites críticos de toxicidade ao alumínio para a produção de café, em torno de $29,6 \mathrm{cmol} \cdot \mathrm{dm}^{-3}$. 


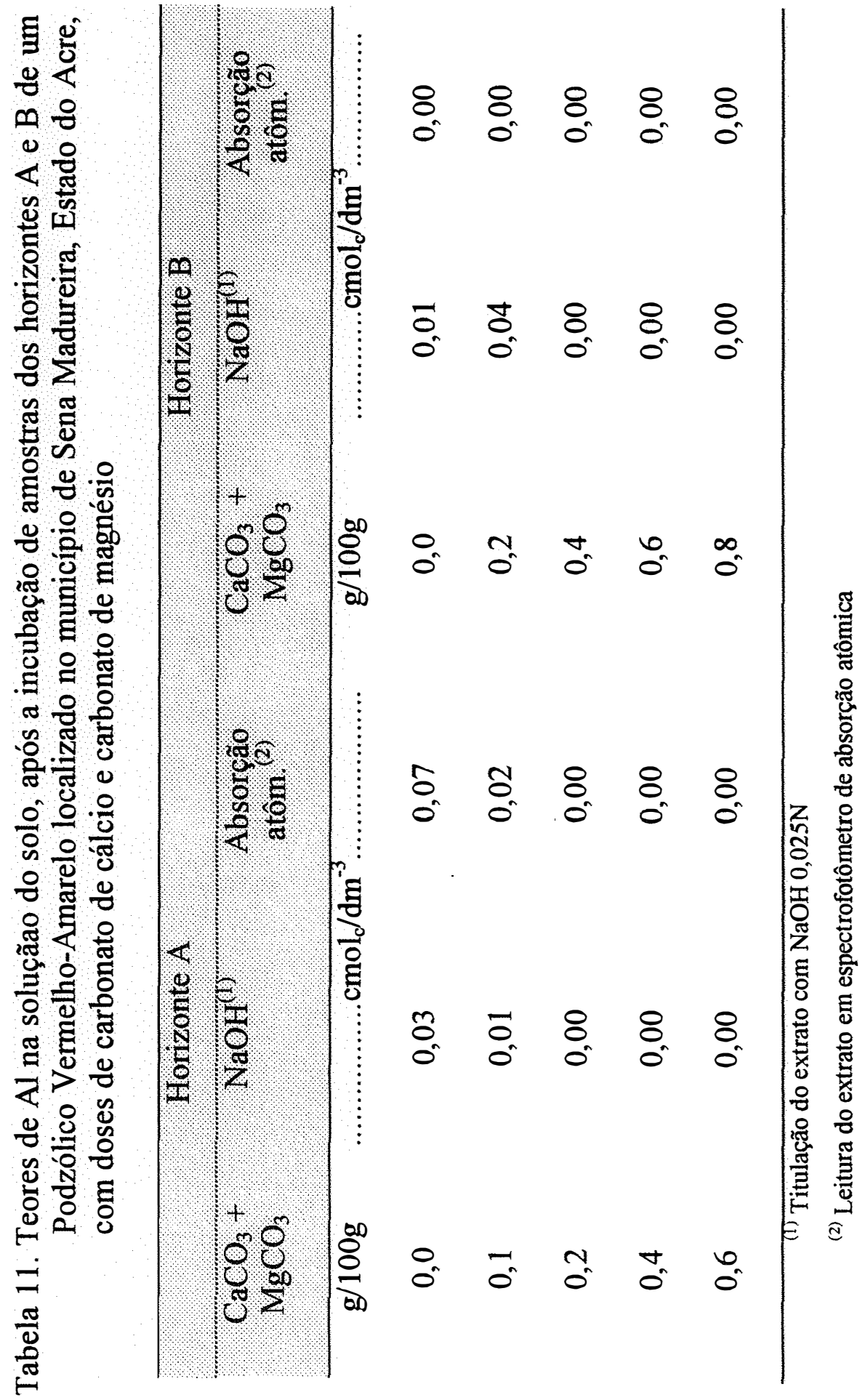




\section{5 - CONCLUSÕES}

Com base nos resultados obtidos pode-se concluir que:

a) os teores de $\mathrm{Al}$ trocável extraído com $\mathrm{KCl} 1 \mathrm{~N}$ e titulado com $\mathrm{NaOH}$ mostraram-se coerentes com os fornecidos por espectrofotometria de absorção atômica;

b) a produção de material seco e a absorção de $\mathrm{Al}, \mathrm{N}, \mathrm{P}$ e K pelas plantas foram pouco influenciadas pelo teor de $\mathrm{Al}$ trocável do solo;

c) não houve relação clara entre os teores de $\mathrm{Al}$ trocável no solo e o desenvolvimento ou presença de sintomas de toxicidade em plantas de arroz, feijão e milho;

d) o solo estudado possui teores de Al trocável muito baixos ou mesmo nulos na solução o que explica a ausência de sintomas de toxicidade ao alumínio nas plantas e a pequena influência desse elemento sobre o desenvolvimento e a absorção de nutrientes pelos vegetais;

e) o teor de alumínio trocável não constitui índice adequado para se estimar a toxicidade desse elemento no solo estudado. 


\section{REFERÊNCIAS BIBLIOGRÁFICAS}

ADAMS, F. Crop response to lime in the Southern United States. In: ADAMS, F., ed. Soil acidity and liming. 2.ed Madison, ASA, 1984. p. 212-66.

ADAMS, F \& LUND, Z.F. Effect of chemical activity of soil solution aluminum on cotton root penetration of acid subsoils. Soil Science, Baltimore, 101:193-8, 1966.

ALVA, A. K.; EDWARDS, D. G.; ASHER, C.J.; BLAMEY, F. P. Effects of phosphorus/aluminum molar and calcium concentration on plant response to aluminum toxicity. Soil Science of A merican Journal, Madison, 50 : 113-37, 1986.

ANDREW, C.S.; JOHNSON, A.D.; SANDLAND, R.L. Effect of aluminum on the growth and chemistry composition of some tropical and temperate pasture legumes. Australian Journal of Agricultural Research, East Melbourne, 24: 325-39, 1973. 
ARMINGER, W. H.; FOY, C.D.; CALDWELL, B.E. Differential tolerance of soybean variaties to an acid soil high in exchangeable aluminium, Agronomy Journal, Madison, 60: 67-70, 1968.

BLACK, C.A. Soil acidity. In: BLACK, C.A. Soil-Plant relationships. 2ed. New York, John Wiley, 1968. p 273-355.

BLAMEY, F.P.C.; EDWARDS, D.G.; ASHER, C.J. Effects of aluminium, $\mathrm{OH}-\mathrm{Al}$ and molar ratio and ionic strenght on soybean root elongation in solution culture. Soil Science, Baltimore, 136(4) 197-207, 1983.

BRASIL, Ministério das Minas e Energia. Departamento Nacional de Produção Mineral. Projeto RADAMBRASIL. Folha SC 19-Rio Branco; geologia geomorfologia, pedologia, vegetação e uso potencial das terras. Rio de Janeiro. 1976. 464p. (Levantamento de Recursos Naturais, 12).

BUENO, N. Quantidade de alumínio no substratoafetando o desenvolvimento, a sintomatologia de toxicidade, a concentração e o acúmulo de macro e micronutrientes em seringueira (Hevea ssp). Piracicaba, 1987. 92p. (Doutorado - Escola Superior de Agricultura Luiz de Queiroz/USP). 
CALBO, A.G. \& CAMBRAID, J. Efeito do alumínio sobre a absorção e sobre o transporte de fósforo em duas cultivares de sorgo (Sorghum bicolor L. Moench). Revista Ceres, Viçosa, 27: 615-25, 1980.

CARVALHO, M.C.S. Sulfato de cálcio, fosfogesso e carbonato de cálcio na melhoria do ambiente radicular de subsolos ácidos. Piracicaba, 1994. 84p. ( Mestrado - Escola Superior de Agricultura Luiz de Queoroz/USP).

CAMARGO, L.S.; CAMPOS, H.E.; ABRAMIDES, E. Influência da calagem em solo ácido da formação glacial na produção do tomateiro. Bragantia, Campinas, 24: 51-4, 1965.

CAMARGO, O.A. \& FURLANI, P.R. Alumínio no solo: concentração, especiação e efeito no desenvolvimento radicular. In: SIMPÓSIO AVANÇADO DE SOLOS E NUTRIÇÃO DE PLANTAS, 2., Piracicaba, 1989. Anais. Campinas, Fundação Cargill, 1989. p. 4569.

CAMBRAIA, J. Mecanismos de tolerância à toxidez de alumínio em plantas. In: REUNIÃO BRASILEIRA DE FISIOLOGIA VEGETAL, 2., Piracicaba, 1989. Anais. Piracicaba, Sociedade Brasileira de Fisiologia Vegetal, 1989. p. 85-92. 
CHAVES, J. C. D.; PAVAN, M. A.;MIYAZAWA, M. Especiação química da solução do solo para interpretação da absorção de cálcio e alumínio por raízes de cafeeiro. Pesquisa Agropecuária Brasileira, Brasília, 26 (3) : 447-53, 1991.

CLARK, R.B. e BROWN, J.C. Differencial phosphorus uptake by phosphorus-stressed corn inbreds. Crop Science, Madison, 14: 5058,1974 .

CLARKSON, D.T. Aluminium in species within the genus Agrostis. Journal of Ecology, New York, 54: 167-78, 1966a.

CLARKSON, D.T. Effects of $\mathrm{Al}$ on the uptake and metabolism of phosphorus by barley seedlings. Plant Physiology. Baltimore, 41: 165-72, 1966b.

CLARKSON, D.T. The effect of aluminum and other trivalent metal cations on cell division in root apices of Allium cepa. Ann. Bot. N. Ser., London, 29: 309, 1965.

COLEMAN, N.T. \& TOMAS, G.W. The basic chemistry of soil acidity. In:PERSON, R.W. \& ADAMS, F. Soil acidity and liming. Madison, American Society of Agronomy, 1967. p. 1-41. (ASA. Agronomy Monograph, 12) 
EMPRESA BRASILEIRA DE PPESQUISA AGROPECUÁRIA. Serviço

Nacional de Levantamento e Conservação de Solos. Manual de Métodos de análise de solos. Rio de Janeiro, 1979. 255p.

FAGERIA, N.K.; BALIGAR, U.C.; WRIGHT, R.J. Aluminum toxicity in crop plants. Journal of Plant Nutrition, New York, 11: 303-19, 1988.

FAGERIA, N.K. \& KLUTHCOUSKI, J. Metodologia para avaliação das culturas de arroz e feijão, para condições adversas de solo. Goiânia, EMBRAPA/CNPAF, 1980. 22p. (EMBRAPA-CNPAF. Circular Técnica, 8).

FAGERIA, N.K.; WRIGHT, R.J.; BALIGAR, V.C. Rice cultivar response to aluminum in nutrient solution. Comunications in Soil Science Plant Analysis, New York 19, (v. 7/12): p. 1133-42, 1988.

FAGERIA, N.K. \& ZIMMERMANN,F.J.P. Seleção de cultivares de arroz para tolerância de alumínio em solução nutritiva. Pesquisa Agropecuaria Brasileira, Brasília, 14(2):141-7, 1979.

FOY, C.D. Effect of aluminum on the uptake and metabolism of phosphorus by barley seedling. Plant Physiology, Rockyille, 41: 165-72, 1966. 
FOY, C.D. Effects of aluminum on plant growth. In: CARSON, E.W., ed. The plant root and its environment. 2. ed. Charlottesville, University Press of Virginia, 1974a. p. 601-42.

FOY, C.D. Effects of aluminum on plant growth. In: CARSON, E.W., ed. The plant root and its environment. Charlottesville, Univ. Press of Virginia, 1974b. p. 601-42.1978.

FOY, C.D. Plant adaptation to mineral stress in problem soil. Iowa State Journal of Research, Ames, 57: 339-54, 1983.

FOY, C.D. Soil chemical factors limiting plant root growth. In: HATFIEL, J.L. \& STEWART, B.A. Limitations to plant root growth. New York, Springer-Verlag, 1992. p. 97-149.

FOY, C.D. \& FLEMING, A.L. The physiology of plant tolerance to excess available aluminium and manganese in acid soils. In: JUNG, G.A., ed. Crop tolerance to subtropical land conditions. Madison, 1978. p. $301-28$.

FOY, C.D.; CHANEY,R.L.; WHITE,M.C. The physiology of metal toxicity in plants. Annual Review of Plant Phisiology, Palo Alto,CA. 29: 511-66, 1978. 
FOY, C.D.; FLEMING, A.L.; GERLOFF, G.L. Differential aluminium tolerance in two snapbean varieties. Agronomy Journal, Madison, 64: 815-8, 1972.

FOY, C.D.; ARMIGER, W.H.; BRIGGLE, L.W.; REID, D.A. Differential aluminum tolerance of two wheat varieties associated with. Plant induced $\mathrm{pH}$ changes around their roots. Soil Science Society of America Proceedings, Madison, 29: 64-7, 1965a.

FOY, C.D.; ARMINGER, W.H.; BRIGGLE, L.W.; REID, D.A. Differential aluminum tolerance of wheat and barley varieties in

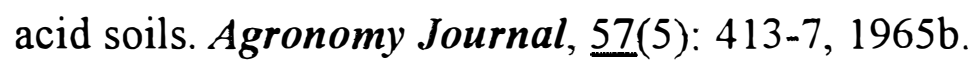

FOY, C.D.; FLEMING, A.L.; BURNS,G.R.; ARMINGER, W.H. Characterization of differential aluminum tolerance among varieties of wheat and barley. Soil Science Society of American Proceedings, Madison, 31: 513-21, 1967.

FOY, C. D.; GERLOFF, G. C.; GABELMEN, W. H. Differencial effets of aluminum on the vegetative grown of tomato cultivars in acid soils and nutrient solution, Journal of the American Society for Horticultural Science, Madison, 98 : 427-32, 1973. 
FRINK, C.D. \& PEECH, M. Hydrolysis and exchange reactions of the aluminum ion in hectorite and montmorillonite suspensions. Soil Science Society of America Proceedings, Madison, 27: 527-30, 1963.

FURLANI, P.R. Efeitos fisiológicos do alumínio em plantas. In: SIMPÓSIO AVANÇADO EM SOLOS E NUTRIÇÃO DE PlANTAS, 2., Piracicaba, 1989. Anais. Campinas, Fundação Cargill, 1989. p.73-90.

FURLANI, P.R. \& BERTON, R.S. Atividade de cálcio e alumínio e desenvolvimento radicular. In: SEMINÁRIO SOBRE O USO DO GESSO NA AGRICULTURA, 2., Uberaba, 1992. Anais. Uberaba. IBRAFOS, 1992 p. 121-38.

GAMA, J.R.N.F. Caracterização e formação de solos com argila de atividade alta Estado do Acre. Itaguaí, 1986. 150p. ( Mestrado Universidade Federal Rural do Rio de Janeiro).

GOMES, F.P. Curso de estatística experimental. 4 ed. São Paulo, Nobel, 1970. 430p. 
GOMES, T.C. de A. \& CAMPOS, I.S. Sistemas de cultivo com leguminosas e seus efeitos sobre a produtividade das culturas $e$ propriedades em um solo no Acre. Rio Branco, EMBRAPA/UEPAE - Rio Branco, 1990. 5p. (EMBRAPA-UEPAE

- Rio Branco. Pesquisa em Andamento, 63).

GRIME, J.P. \& HODGSON, J.G. An investigation of the ecological significance of lime chlorosis by means of large scale comparative experiments. In: RORISON, I.H., ed. Ecological aspects of the mineral nutrition of plants. Oxford, Blackwell Scientific, 1969. p.67-9.

HACHETT, C. Stimulative effects of aluminium on plant growth. Nature, London, 195: 471-2, 1962.

HELYAR, K.R. Effects of aluminum and manganese toxicity growth. In: Mineral nutrition of legumes. In: ANDREW, C.S. \& KAMPRATH, E.J., ed. Tropical and subtropical soil. Melbourne, CSIRO, 1978. p. 207-31.

HUCK, M.G. Impairments of sucrose utilization for cell wall formation in the roots of aluminium damaged cotton seedlings. Plant and Cell Physiology,. Osaka, 13: 7-14, 1972. 
JACKSON, W.A. Physiological effects of soil acidity. In: PEARSON, R.W. \& ADAMS, F., ed. Soil acidity and liming. Madison, American Society of Agronomy, 1967. p. 43-124.

JOHNSON, R.E. \& JACKSON, W.A. Calcium uptake and transport by wheat seedings as affected by aluminum. Soil Science Society of America Proceedings, Madison, 28: 381-6, 1964.

KINRAIDE, T.B. \& PARKER, D.R. Cation amelioration of aluminum toxicity in wheat. Plant Physiology, Lancaster, 85: 546-51, 1987.

LEE, C.R. Influence of aluminium on plant growth and mineral nutrition of potatoes. Agronomy Journal, Madison, 63: 604-8, 1971.

LEVAN, A. Cytological reations induced by inorganic solution. Nature, London, 156: 751-2,1945.

MAGISTAD, O.C. The aluminum content of the soil solution and its relation to soil reaction and plant growth. Soil Science,Baltimore, 20: $181-226,1925$.

MALAVOLTA, E. Elementos de nutrição mineral de plantas. São Paulo, Agronômica Ceres, 1980. 251 p.

MALAVOLTA, E.; VITTI, G.C.; OLIVEIRA, S.A. de. Avaliação do estado nutrição das plantas. Piracicaba, Potafos, 1989. $201 \mathrm{p}$. 
MALAVOLTA, E.; VITTI, G.C.; OLIVEIRA, S.A. de. Avaliação do estado nutrição das plantas. Piracicaba, Potafos, 1989. $201 \mathrm{p}$.

MATSUMOTO, H.; MORIMURA, S.; TAKAHASHI, E. Less involvement of pectin in the precipitation of amonium in pea roots. Plant and Cell Physiology, Kyoto, 18: 325-35, 1977.

MATSUMOTO, H.; SAWA,H.E.; TURIKAI,H.; TAKAHASHI,E. Localization of absorbed aluminium in pea root and its binding to nucleic acids. Plant and Cell Physiology,Tokyo, 17: 127-37,1976.

McLEAN, E.O. Aluminum. In: BLACK,C.A., ed. Methods of soill analysis. v.2:Chemical and microbiological properties. Madison, American Society of Agronomy, 1965. p.978-98.

MENGEL, K. \& KIRKBY, E.A. Principles of plant nutrition. 4. ed. Bern, International Potash Institute, 1987. 687p.

MESQUITA FILHO, M.V. \& SOUZA, A.F. Resposta do tomateiro à aplicação da calagem e da adubação fosfatada. In: CONGRESSO BRASILEIRO DE OLERICULTURA, 26. Salvador, 1986. Resumos. Horticultura Brasileira, Brasília, 4: 61, 1986. 
MALAVOLTA, E.; VITTI, G.C.; OLIVEIRA, S.A. de. Avaliação do estado nutrição das plantas. Piracicaba, Potafos, 1989. $201 \mathrm{p}$.

MATSUMOTO, H.; MORIMURA, S.; TAKAHASHI, E. Less involvement of pectin in the precipitation of amonium in pea roots. Plant and Cell Physiology, Kyoto, 18: 325-35, 1977.

MATSUMOTO, H.; SAWA,H.E.; TURIKAI,H.; TAKAHASHI,E. Localization of absorbed aluminium in pea root and its binding to nucleic acids. Plant and Cell Physiology, Tokyo, 17: 127-37,1976.

McLEAN, E.O. Aluminum. In: BLACK,C.A., ed. Methods of soill analysis. v.2:Chemical and microbiological properties. Madison, American Society of Agronomy, 1965. p.978-98.

MENGEL, K. \& KIRKBY, E.A. Principles of plant nutrition. 4. ed. Bern, International Potash Institute, 1987. 687p.

MESQUITA FILHO, M.V. \& SOUZA, A.F. Resposta do tomateiro à aplicação da calagem e da adubação fosfatada. In: CONGRESSO BRASILEIRO DE OLERICULTURA， 26. Salvador, 1986. Resumos. Horticultura Brasileira, Brasília, 4: 61, 1986. 
MUGWIRA, L.M.; ELGANARY, S.M.; PATEL, K. Diferential tolerance of triticale, wheat rye and barley on aluminium in nutrient solution. Agronomy Journal, Madison, 68: 782-7, 1978.

MULLITTE, K.J. Stimulation of growth in Eucalyptus due to aluminium. Plant and Soil, The Hague, 42: 495-9, 1975.

OLIVEIRA, L.E.M. Crescimento e comportamento nutricional de cultivares de mandioca (Manihot esculenta, Grantz) submetidas à niveis de aluminio. Viçosa, 1979. 39p. (M.S. - Universidade Federal de Viçosa).

OLMOS, J.I.L. \& CAMARGO, M.N. Ocorrência de aluminio tóxico nos solos do Brasil; sua caracterização e distribuição. Ciência e Cultura, São Paulo, 28(2): 171-80, 1976.

PARQUER， D.R.; KINRAIDE,T.B. ; ZELAZNY,L.N. On the phytotoxicity of polimeclear hidroxid-aluminum complexes. Soil Science Society of America Journal, Madison, 53: 789-96, 1989.

PAVAN, M.A. Efeitos tóxicos de alumínio em mudas de cafeeiro em relação à nutrição de cálcio. Revista Brasileira de Ciência do Solo, Campinas, 6: 209-13, 1982. 
MUGWIRA, L.M.; ELGANARY, S.M.; PATEL, K. Diferential tolerance of triticale, wheat rye and barley on aluminium in nutrient solution. Agronomy Journal, Madison, 68: 782-7, 1978.

MULLITTE, K.J. Stimulation of growth in Eucalyptus due to aluminium. Plant and Soil, The Hague, 42: 495-9, 1975.

OLIVEIRA, L.E.M. Crescimento e comportamento nutricional de cultivares de mandioca (Manihot esculenta, Grantz) submetidas à níveis de alumínio. Viçosa, 1979. 39p. (M.S. - Universidade Federal de Viçosa).

OLMOS, J.I.L. \& CAMARGO, M.N. Ocorrência de alumínio tóxico nos solos do Brasil; sua caracterização e distribuição. Ciência e Cultura, São Paulo, 28(2): 171-80, 1976.

PARQUER, D.R.; KINRAIDE,T.B. ; ZELAZNY,L.N. On the phytotoxicity of polimeclear hidroxid-aluminum complexes. Soil Science Society of America Journal, Madison, 53: 789-96, 1989.

PAVAN, M.A. Efeitos tóxicos de alumínio em mudas de cafeeiro em relação à nutrição de cálcio. Revista Brasileira de Ciência do Solo, Campinas, 6: 209-13, 1982. 
PAVAN, M.A. \& BINGHAM, F.T. Toxidez de alumínio em cafeeiros cultivados em solução nutritiva. Pesquisa Agropecuária Brasileira, Brasilia, 17(9): 1293-302, 1982.

PAVAN, M. A. \& BINGHAM, F.T. Toxicity of aluminum to coffee seedllings grown in nutrients solution. Soil Science of American Journal, Madison, 46 (5) : 993-7, 1982.

PAVAN, M.A.; BINGHAM, F.T.; PRATT, P.F. Redistribution of exchangeable calcium, magnesium and aluminum following lime or gypsum applictions to a Brazilian Oxisol. Soil Science Society of America Journal, Madison, 48(1): 33-8, 1984.

POMBO, G.I. \& SMITH, C.B. Growth and nutrient interrelashionships of three vegetable crops with different sensitivities of soil $\mathrm{pH}$ as affected by lime and fertilizer treatments. Comunications. In: Soil Science and Plant Analysis, New York, 17: 353-68, 1986.

RAGLAND, J.L. \& COLEMAN, N.T. The hydrolisis of aluminum salts in clay and soil sistems. Soil Science Society of America Proceedings, Madison, 24: 457-60, 1960.

RASMUSSEN, H.P. Differential aluminium in Zea mays. Planta, Berlim 81: 27-28, 1968. 
PAVAN, M.A. \& BINGHAM, F.T. Toxidez de alumínio em cafeeiros cultivados em solução nutritiva. Pesquisa Agropecuária Brasileira, Brasília, 17(9): 1293-302, 1982.

PAVAN, M. A. \& BINGHAM, F.T. Toxicity of aluminum to coffee seedllings grown in nutrients solution. Soil Science of American Journal, Madison, 46 (5) : 993-7, 1982.

PAVAN, M.A.; BINGHAM, F.T.; PRATT, P.F. Redistribution of exchangeable calcium, magnesium and aluminum following lime or gypsum applictions to a Brazilian Oxisol. Soil Science Society of America Journal, Madison, 48(1): 33-8, 1984.

POMBO, G.I. \& SMITH, C.B. Growth and nutrient inter relationships of three vegetable crops with different sensitivities of soil $\mathrm{pH}$ as affected by lime and fertilizer treatments. Comunications. In: Soil Science and Plant Analysis, New York, 17: 353-68, 1986.

RAGLAND, J.L. \& COLEMAN, N.T. The hydrolisis of aluminum salts in clay and soil sistems. Soil Science Society of America Proceedings, Madison, 24: 457-60, 1960.

RASMUSSEN, H.P. Differential aluminium in Zea mays. Planta, Berlim 81: 27-28, 1968. 
PAVAN, M.A. \& BINGHAM, F.T. Toxidez de alumínio em cafeeiros cultivados em solução nutritiva. Pesquisa Agropecuária Brasileira, Brasília, 17(9): 1293-302, 1982.

PAVAN, M. A. \& BINGHAM, F.T. Toxicity of aluminum to coffee seedllings grown in nutrients solution. Soil Science of American Journal, Madison, 46 (5) : 993-7, 1982.

PAVAN, M.A.; BINGHAM, F.T.; PRATT, P.F. Redistribution of exchangeable calcium, magnesium and aluminum following lime or gypsum applictions to a Brazilian Oxisol. Soil Science Society of America Journal, Madison, 48(1): 33-8, 1984.

POMBO, G.I. \& SMITH, C.B. Growth and nutrient inter relationships of three vegetable crops with different sensitivities of soil $\mathrm{pH}$ as affected by lime and fertilizer treatments. Comunications. In: Soil Science and Plant Analysis, New York, 17: 353-68, 1986.

RAGLAND, J.L. \& COLEMAN, N.T. The hydrolisis of aluminum salts in clay and soil sistems. Soil Science Society of America Proceedings, Madison, 24: 457-60, 1960.

RASMUSSEN, H.P. Differential aluminium in Zea mays. Planta, Berlim 81: 27-28, 1968. 
REES, W.J. \& SIDRAK, G.H. Interrelationships of aluminum and manganese toxicities toward plants. Plant and Soil, The Hague, 14: 101-17, 1961.

RHOADES, J.R. Soluble salts. In: PAGE, A.L.; MILLER, R.H.; KEENEY, D.R. ed. Methods of soil analysis. 2.ed. Madison, ASA, 1982. p. 167-79 (Agronomy, 9).

RORYSON, I.H. The effect of aluminium on legume nutrition. In: HALLSWORTH, E.G., ed. Nutrient of the legumes. London, Academic Press, 1958. p. 43-61.

ROY, K.A.; SHARMA, A.; TALUKDER, G. Some aspects of aluminum toxicity in plants. The Botanical Review, New York, 54: 145-78, 1988.

SALISBURY, F.B. \& ROSS, C. Plant physiology. Belmont, Wadsworth Publ. 1969. 748p.

SMYTH, T. J. \& CRAVO, M. S. Aluminum and calcium constraints to continuous crop production in a brazilian amazon oxisol. Agronomy Journal, Madison, 84 : 843-50, 1992. 
REES, W.J. \& SIDRAK, G.H. Interrelationships of aluminum and manganese toxicities toward plants. Plant and Soil, The Hague, 14: $101-17,1961$.

RHOADES, J.R. Soluble salts. In: PAGE, A.L.; MILLER, R.H.; KEENEY, D.R. ed. Methods of soil analysis. 2.ed. Madison, ASA, 1982. p. 167-79 (Agronomy, 9).

RORYSON, I.H. The effect of aluminium on legume nutrition. In: HALLSWORTH, E.G., ed. Nutrient of the legumes. London, Academic Press, 1958. p. 43-61.

ROY, K.A.; SHARMA, A.; TALUKDER, G. Some aspects of aluminum toxicity in plants. The Botanical Review, New York, 54: 145-78, 1988.

SALISBURY, F.B. \& ROSS, C. Plant physiology. Belmont, Wadsworth Publ. 1969. 748p.

SMYTH, T. J. \& CRAVO, M. S. Aluminum and calcium constraints to continuous crop production in a brazilian amazon oxisol. Agronomy Journal, Madison, 84 : 843-50, 1992. 
THOMAS, G. J. \& HARGROVE, W. L. The chemistry of soil acidity In: PEARSON, R. W., ed Soil acidity and liming. Madison, Soil Society of America, 1984. p. 3-56.

WAGATSUMA, T. \& EZOE, Y. Effect of $\mathrm{pH}$ on ionic species of aluminum in medium and and aluminum toxicity under solution culture. Soil Science and Plant Nutrition, Tokyo, 31 (4) : 547-61, 1985. 
APÊNDICE 
Tabela 1 . Teor de Al, N, P e K em diferentes plantas cultivadas em amostras de dois horizontes (A e B) de um Podzólico Vermelho-Amarelo do Estado do Acre. tratados ou não com carbonato de cálcio.

\begin{tabular}{|c|c|c|c|c|c|c|c|c|c|c|}
\hline \multirow[t]{2}{*}{ Culturas } & \multirow[t]{2}{*}{ Horizonte } & \multirow[t]{2}{*}{$\mathrm{CaCO}_{3}$} & \multicolumn{4}{|c|}{ Raizes } & \multicolumn{4}{|c|}{ Parte Aérea } \\
\hline & & & $\mathrm{Al}$ & $\mathrm{N}$ & $\mathrm{P}$ & $\mathrm{K}$ & $\mathrm{Al}$ & $\mathrm{N}$ & $\mathrm{P}$ & $\mathrm{K}$ \\
\hline & & & $\mathrm{mg} / \mathrm{kg}$ & $\%$ & $\%$ & $\%$ & $\mathrm{mg} / \mathrm{kg}$ & $\%$ & $\%$ & $\%$ \\
\hline \multirow[t]{4}{*}{ Arroz 1} & $\mathrm{~A}$ & sem & 206,00 & 1,75 & 0,23 & 1,73 & 18,67 & 2,91 & 0,31 & 3,77 \\
\hline & & com & 205,00 & 1,75 & 0,21 & 1,60 & 19,00 & 2,52 & 0,25 & 1,60 \\
\hline & B & sem & 258,00 & 1,65 & 0,32 & 2,15 & 36,67 & 2,69 & 0,45 & 4,42 \\
\hline & & com & 252,00 & 1,71 & 0,32 & 2,08 & 21,00 & 2,61 & 0,45 & 2,08 \\
\hline \multirow[t]{4}{*}{ Arroz 2} & A & sem & 208,33 & 2,89 & 0,31 & 1,80 & 15,00 & 2,89 & 0,34 & 4,02 \\
\hline & & com & 207,67 & 1,32 & 0,23 & 1,65 & 39,67 & 2,67 & 0,27 & 1,65 \\
\hline & B & sem & 266,67 & 2,51 & 0,35 & 2,18 & 36,33 & 2,41 & 0,35 & 3,97 \\
\hline & & com & 243,33 & 2,18 & 0,43 & 2,32 & 27,00 & 3,10 & 0,46 & 4,31 \\
\hline \multirow[t]{4}{*}{ Feijão } & A & sem & 210,33 & 2,10 & 0,21 & 1,40 & 38,00 & 2,08 & 0,22 & 1,70 \\
\hline & & com & 223,33 & 2,10 & 0,24 & 1,67 & 32,00 & 2,24 & 0,29 & 2,06 \\
\hline & B & sem & 434,33 & 2,71 & 0,24 & 1,60 & 74,33 & 3,21 & 0,24 & 3,56 \\
\hline & & $\mathrm{com}$ & 262,33 & 2,18 & 0,36 & 2,28 & 101,67 & 2,68 & 0,35 & 2,82 \\
\hline \multirow[t]{4}{*}{ Milho } & A & sem & 226,67 & 0,71 & 0,09 & 0,45 & 15,00 & 0,96 & 0,09 & 1,23 \\
\hline & & com & 211,00 & 0,63 & 0,24 & 0,81 & 18,67 & 1,02 & 0,13 & 1,29 \\
\hline & B & sem & 225,00 & 0,15 & 0,14 & 0,94 & 17,00 & 0,96 & 0,14 & 1,84 \\
\hline & & com & 258,00 & 0,58 & 0,14 & 1,06 & 14,33 & 0,87 & 0,22 & 1,63 \\
\hline
\end{tabular}




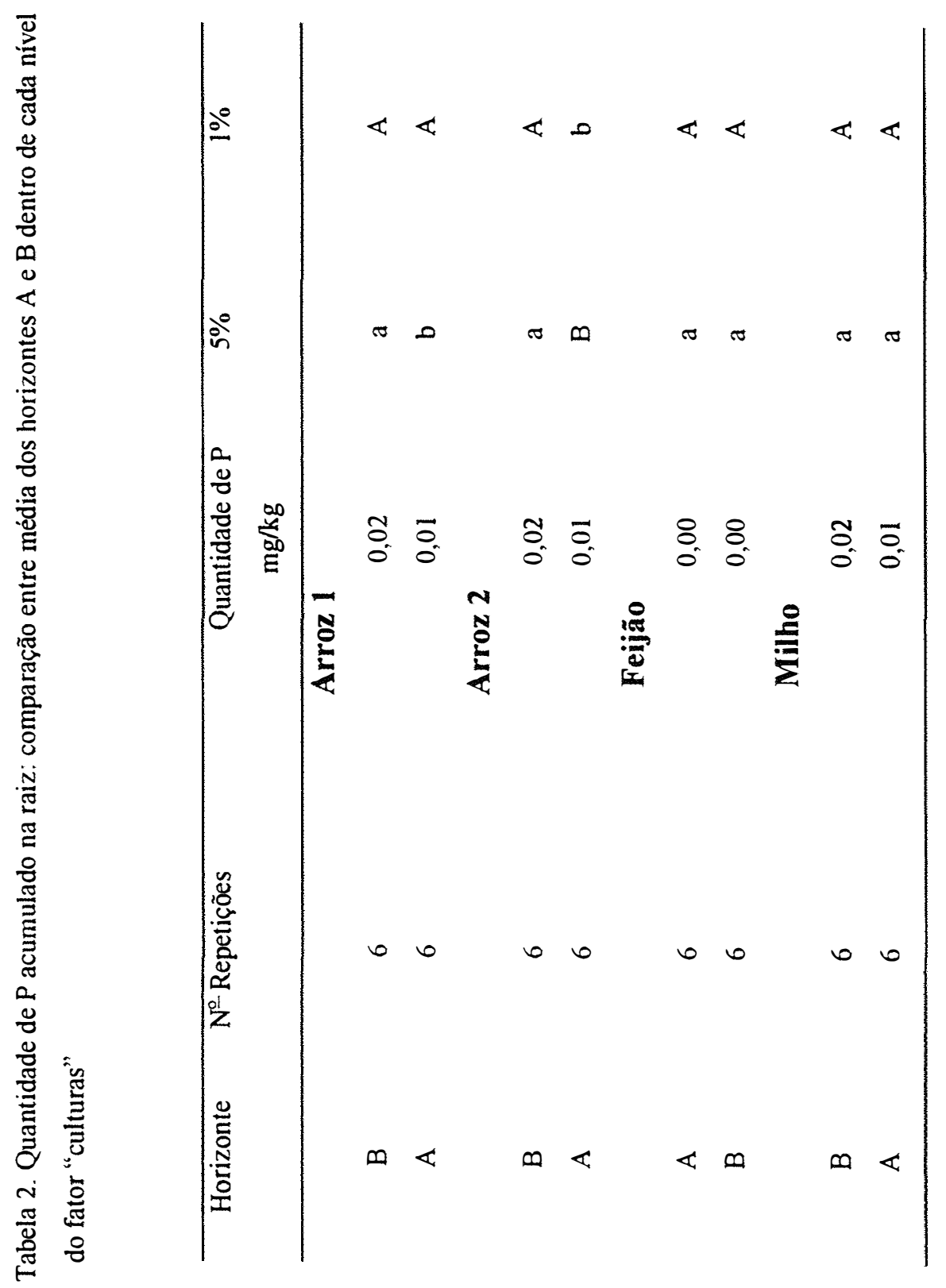

